\title{
Thebasa and the Byzantine-Arab frontier of the Middle Taurus Observations in confinio Lycaoniae atque Ciliciae
}

\author{
Robert D. ROKICKI*
}

To Professor Stephen Mitchell,

\section{Historical sources}

for continued support, patience and inspiration

Thebasa, a settlement of south central Anatolia, occupies a small but distinctive place in history. According to Pliny it lay in Taurus mountains (in Tauro) and together with Hyde was one of the two most prominent (celebrantur) cities of Lycaonia proper (ipsius Lycaoniae). At the same time, he places Hyde on the border of Galatia and Cappadocia, and elsewhere mentions the Thebaseni as one of the peoples of Galatia. ${ }^{1}$

Thebasa and its castle gained new significance after the Muslim conquest of Cilicia, when it became one of the crucial fortresses on the eastern border of Byzantium. In 793, Thebasa surrendered to Abdurrahman bin Abdalmalik's army due to water scarcity; in 805 it was restored on the initiative of Emperor Nikephoros I, and in 806 was destroyed during the great campaign of caliph Harun ar-Rashid. The Emperor pledged he would no longer rebuild the fortress, but he did not keep his promise and the caliph soon took Thebasa again. ${ }^{2}$

From the ninth to the twelfth century, Tibassada, which most scholars identify with Thebasa, was listed in the Notitiae Episcopatuum as a suffragan diocese of Iconium. ${ }^{3}$

\section{Previous identifications and explorations: Kaleköy; Se Kalesi - Kesmez; Divle - Üçharman}

Due to the scanty and ambiguous information, the city has been searched for in various places, often very distant from one another. John A. Cramer argued that Thebasa was Taspa - a town between Iconium and Isaura. Andreas D. Mordtmann identified it with Sifsaf (Hisn as-Safsaf), a fortlet north of the Cilician Gates mentioned in Arabic sources. Hans Rott suspected that Thebasa was 'Süvescha' (Suveş in Cappadocia, now Şahinefendi). ${ }^{4}$ These early confusions derived mostly from misinterpretation or ignorance of sources.

\footnotetext{
* Robert D. Rokicki, British Institute at Ankara (BIAA), Atatürk Bulvarı 154, Çankaya 06700 Ankara, Turkey (robert.d.rokicki@gmail.com; https://orcid.org/0000-0002-2443-7296).

${ }^{1}$ Plin. HN, V 95: "ipsius Lycaoniae celebrantur Thebasa in Tauro, Ide (= Hyde) in confinio Galatiae atque Cappadociae, and 147 (a list of communities in Galatia): praeter hos celebres Attalenses, Arassenses, Comenses, Dicitenses, Hierorenses, Lystreni, Neapolitani, Oeandenses, Seleucenses, Sebasteni, Timoniacenses, Thebaseni." The discrepancy arising from that Lycaonia was, in Pliny's time, administratively part of the province Galatia, caused some difficulties in later attempts to locate Thebasa; more on this issue: Perrot - Guillaume 1872, 194; Laminger-Pascher 1992, 108-09.

${ }^{2}$ Theophanes 469, 481-82; Mich. Syr. III 8-9; Tabari, III 628, 709.

${ }^{3}$ Darrouzès 1981,$77 ; 7,434 ; 9,326 ; 10,383 ; 13$, 389. Laminger-Pascher 1992, 109-9 has a different opinion on this subject.

${ }^{4}$ Cramer 1832, 74; Mordtmann 1861, 182-84; Rott 1908, 286 n. 1. It was Michael the Syrian who had placed it in Cappadocia.
} 


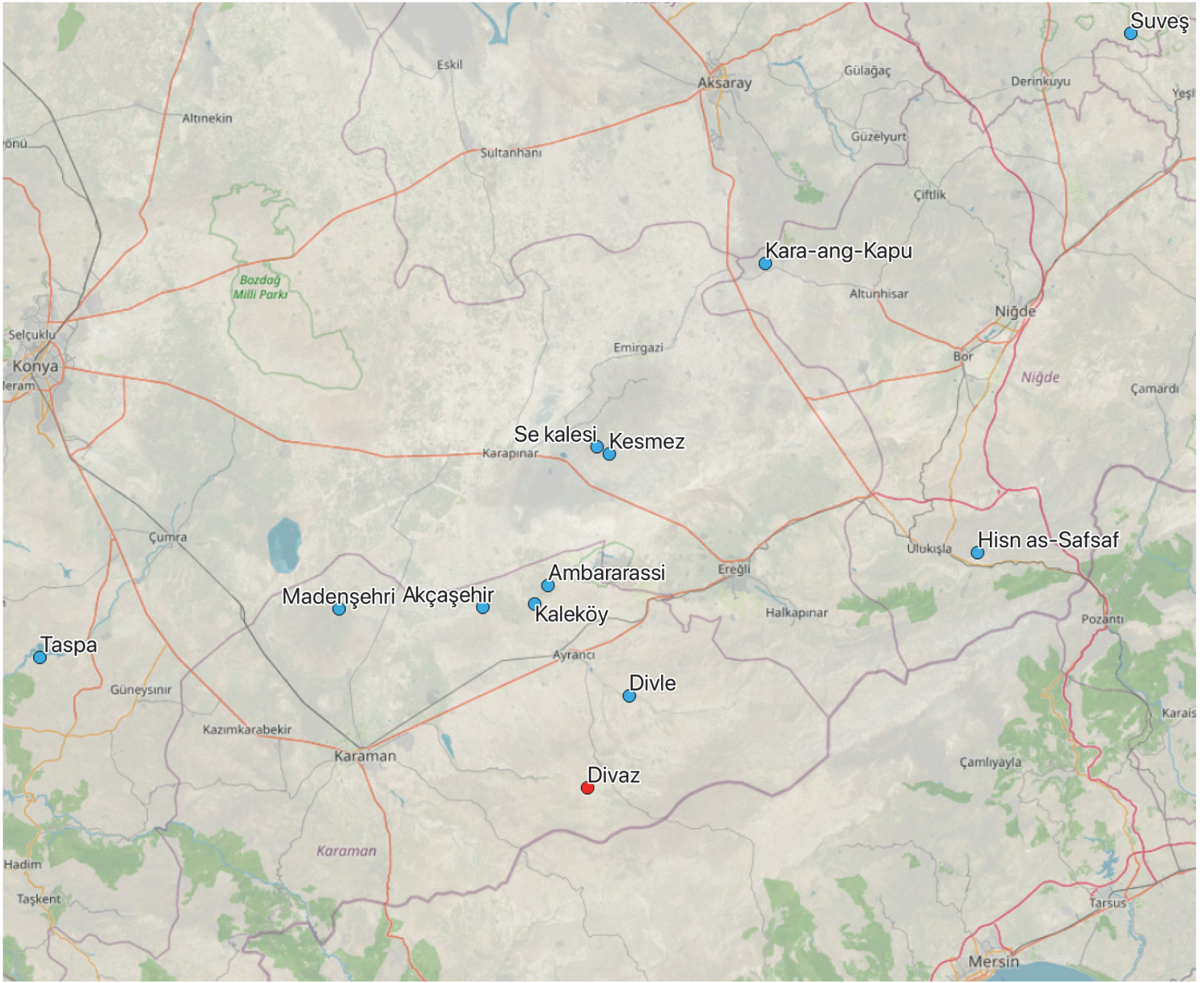

Map 1) Attempts to localize Thebasa (Bing Satellite/OSM Standard compiled by M. Kamieniak)

William M. Ramsay, analyzing the Notitiae Episcopatuum, in which Thebasa and Hyde alternately appear and disappear, speculated that both were a single center, except that Hyde was a lowland city, and Thebasa a mountain fortress. Based on this assumption, he considered several locations, first Ambararassi (now Ambar), then Kara-ang-Kapu (now Keçikalesi). He also took into account Madenşehri in the Kara Dağ range, famous for its "thousand and one churches", ${ }^{5}$ but finally dismissed all these eventualities, selecting Akçaşehir (as the city) and Kaleköy about 10 kilometers away (as the castle). ${ }^{6}$

The shortcomings of the Kaleköy hypothesis are that it is a long way from the Taurus, is situated in the plain, and has no defensive emplacements. Although kale means castle, the village owes its name to ruins which up until recently stood on a nearby mound, which is gentle and devoid of defensive qualities, and was rather an ecclesiastical or residential facility, as can be deduced from the spolia that are to be seen there.

Another argument against Ramsay's suggestions is that Pliny called Thebasa and Hyde the most outstanding cities of Lycaonia, clearly distinguishing their locations. Nevertheless, the idea of an

\footnotetext{
${ }^{5}$ Ramsay 1890, 339-341; Ramsay - Bell 1909, 560.

${ }^{6}$ Ramsay 1904, 87.
} 
agglomerate remained attractive for a long time, and A. H. M. Jones even went further with a theory that as many as three urban centers might have "amalgamated" into one. ${ }^{7}$

Gertrude Bell posited that Thebasa was Se Kalesi, a fortress in Karaca Dağ. She also drew attention to the ruins at Kesmez below, which she was not able to examine. W. M. Ramsay, and later Klaus Belke adopted her idea, identifying Thebasa with Kesmez. Belke noted late Roman and Byzantine spolia there, as well as a sizeable farm built on the church remains. ${ }^{8}$ It should be noted, however, that Kesmez is situated on dry, stony slopes, quite distant from significant roads and tracks. It could at best be a major pastoral center, but it is hard to imagine a town ever functioning there.

It is unrealistic for these reasons to suppose that the site had an ancient origin, and there are indications that Kesmez developed in response to Arab razzias, like a number of other small settlements at the foot of Karaca Dağ, sheltered by the mountain range and by castles. The village lies at the mouth of a gorge, leading to a valley with a spring. Fragmentary defensive structures remain where the gorge narrows, probably intended to keep out unwanted visitors. In case of emergency, the people of Kezmez could quickly retreat into the valley and barricade the narrow entrance. Assailants could theoretically try to break into the valley from the west - as I did but it was hard, time consuming, and would have exposed them to attack from the castle, which stood high above this path. The position of the castle is another relevant factor. Michael the Syrian reported that in 793 Thebasa capitulated after four hundred of its defenders died of thirst. It is safe to assume that a much greater number had taken refuge there. There is not enough space for such a multitude in Se Kalesi, which is hard to reach from Kesmez, let alone from other, more remote settlements. It seems evident that it was the valley with a spring that provided shelter to local inhabitants, and not this windswept stronghold in clouds.

The castle of Se Kale served as a citadel and a guardhouse, part of the Byzantine early warning system perhaps. A modest party, able to deliver a short, precise blow, was probably stationed there. It is equally difficult to imagine how Se Kalesi could have been besieged or subdued. It is an eagle's nest, high and inaccessible. The approach to its walls from the plain requires three hours of hard climbing. The Muslim attackers did not dissipate their time and resources on such castles, which offered neither a great threat nor the expectation of booty. In fact, they seized Thebasa three times, over the course of thirteen years, which suggests that it was not a very challenging task. For comparison, nearby Heraclea (Ereğli) surrendered only once, to a force of over 70,000 soldiers, equipped with siege engines, commanded by Harun ar-Rashid in person, at the end of a siege which lasted a whole month. ${ }^{9}$

The question remains, where did the range of spolia at Kesmez come from? It can be answered by the analogy of nearby Karapinar: Ramsay, judging from the structural elements he saw accumulated there, thought that the site, was ancient. Belke stated however, that these spolien were most likely brought from Dağören. ${ }^{10}$ The provenance of the Kesmez stones might have been

\footnotetext{
7 The third being Sidamaria. Jones 1971, 136.

${ }^{8}$ Ramsay - Bell 1909, 492, 569; Belke 1984, 233-34. A photograph from late 70s shows a vaulted nave.

${ }^{9}$ This "70,000" is a literary figure of speech, meaning very many. It is not to be mistaken for a literal number. I want to thank T. M. P. Duggan for pointing this out.

${ }^{10}$ Belke 1984, 187.
} 
similar. It is hard to ascertain this claim now, as there is no trace of them in situ. In the 1980 s, the village moved into the plain, two kilometers below the earlier location, and carted the most valuable building material with them. Thus, the inscribed stones of Kesmez did not cease their peregrinations and were employed in new houses. When the memory of their origin perishes, someone will perhaps infer from them the antique origin of a village founded some forty years ago.

Even if the process did not run exactly this way, the pattern reflects a universal axiom, that people fled to the mountains in turbulent times and returned to the plains when threats passed. In any case, 'famous' Thebasa could not have existed here, since the physical environments could not have supported it.

But this is not the only circumstance that disqualifies this and the other aforementioned locations. Despite his ambiguity, Pliny clearly pointed towards the Taurus. Taking note of this, Walther Ruge already speculated that Thebasa might have lay deeper in the mountains. ${ }^{11}$ Based on these assumptions and the conviction the town was situated close to important routes, Gertrud Laminger-Pascher pointed to Divle (now Üçharman), at the supposed intersection of roads, running north from Cilicia and east-west from Ereğli to Karaman. In support, she cited a number of travelers' accounts from the nineteenth century who passed by Divle. ${ }^{12}$

Divle is an important spot, but G. Laminger-Pascher slightly overestimated it. This is already noticeable from the references she invoked herself: Charles Texier noted a complete lack of "works of antiquity... and any evidence that would allow to attribute a very old origin to this place". He admitted some role of Divle in Byzantine times due to its location "in the center of the valley", but it did not explain the prominence that Thebasa held according to Pliny. ${ }^{13}$ William J. Hamilton, in turn, wrote that he only heard that Divle lay on the Ereğli - Karaman route. ${ }^{14}$ The English traveler E. J. Davis gave the most complete account of Divle, but, ironically, questioned the settlement's significance, emphasizing its inaccessible position amid steep gorges and waterless wasteland, as well as the scarcity of arable land, which caused the local economy to be based on shepherding. ${ }^{15}$

Little else is known. Ch. Texier reported "well preserved" ruins of the church. Davis did not mention this, and the omission is significant as he spent a day here, took interest in antiquities,

\footnotetext{
${ }^{11}$ „Vielleicht lag T(hebasa) weiter im Gebirge”, Ruge 1934, 1594.

${ }^{12}$ Laminger-Pascher 1992, 110.

13 "Les ouvrages de la haute antiquité et de la période grecque manquent absolument; on n'a donc aucune preuve certaine qui permette d'assurer à cette place une origine très ancienne; mais elle fut importante sous l'empire byzantin. Sa position au center d'une vallée qui va jusqu'au Taurus, en fait un poste utile pour arrêter les incursions des montagnards." Texier 1849, 130. And it should be remembered that Ch. Texier did not wish to underplay the importance of Divle, which he considered to be the site of ancient Derbe.

${ }^{14}$ Hamilton 1842, 313.

15 "In the valley, along the stream, is a small extent of cultivated land, but it was always from their flocks that the people derived their chief support. The position of the place is very inaccessible, being many hours from any other village, in a sterile and inhospitable wilderness, seamed with deep ravines." Davis 1879, 268.
} 
examined rock tombs and provided lots of details on various topics. The castle is even more enigmatic. Texier mentioned its remnants. Davis was told about the "old city," but upon learning there were only outlines of the walls left, gave up sightseeing. ${ }^{16}$ In his comprehensive Erdkunde, Carl Ritter communicated that "Upon a limestone wall four hundred feet high ... on the north side of the valley, there is a citadel, whose foundation seems to date back to Roman, if not earlier times." He did not reveal though, where he got this information from. ${ }^{17}$

During the course of four visits between July 2018 and November 2019, I thoroughly examined the plateau above Divle over a distance of about 3 kilometers and at depth of 100 to 500 meters, with particular emphasis on the dominant points and descents to the valley. I did not find any signs of any building there. When I inquired about the castle, local residents pointed to the caves in the center of the village. That this might be a proper castle is confirmed by the most authoritative in this respect, Konyal,, who drew comparison to similar cave complexes in vicinity. Some of the interviewees pointed more specifically to a spot called Kalekapı or Kaleönü (which respectively means: "castle gate" and "outer bailey"). This also is reflected in Konyal, who alluded to a vanished palace of some Ottoman bey, that was once standing there. ${ }^{18}$ There is a small modern cemetery today and a panel with an inscription "Kaleönü bizans mezarllğı" (Byzantine graveyard). However, there are no visible historic burials and nobody could say anything reasonable about it. Among the weathered rock formations an unused path winds up to the plateau. It seems to have been the main road once. Some fortifications could be expected, but there is nothing of that kind there. Given the predominantly lithospheric bed around, it is possible that if the hypothetical castle was demolished to the ground, there would be no trace of it left.

On the opposite, south side of the valley, Divle Obruk, the principal attraction of Üçharman is a vertical, entirely closed rock pocket with a depth of up to 36, length 250, and width of at most three meters. Because of its extraordinary shape, this serves as a ripening cellar of a renowned, local cheese, which is favored by its microclimate and the constant temperature inside. Access to the cave is through a narrow shaft. A treadmill used to work here, recently replaced with an electric elevator. This geological phenomenon was undoubtedly utilized in the distant past as well. Old photographs show the shaft was underpinned. Some foundations are noticeable around the entrance too. Buried in earth, I discovered them by accident due to ongoing works, that have brutally exposed them. It is difficult to assess the extent of the site, but these might be vestiges of the "old city" that Davis declined to visit. It is not difficult to envisage that if there once was a food warehouse, at least there would have been a tower to guard the entrance. Was this Texier's castle? ${ }^{19}$

\footnotetext{
${ }^{16}$ Instead he went to see rupestrian tombs. To this end, he moved deeper into the valley whose slope he describes as "perfectly honeycombed." This might have been in Inönü. Otherwise this spot is not securely identified either.

${ }^{17}$ Ritter 1859, 304.

${ }^{18}$ Konyalı 1970, 839, 846-49.

${ }^{19}$ Such a conclusion can be drawn from his remark that the stronghold protected Divle from "highlanders" (montagnards). After all, the Arabs were basically coming from the north and not associated with highlanders.
} 
This is good moment to recall that castles in the borderlands emerged mostly in response to Arab raiding and as a purely functional phenomenon, serving primarily as watchtowers (phrouria), and then refuges (kataphygia), and that is why caves and even locked valleys were given these names. Based on that, the cave complex in Divle could indeed constitute the castle proper. Whatever, though, was called a castle here, it had to be of limited size, unable to accommodate hundreds of people. The same applies to the settlement itself, more pastoral than agricultural, squeezed in a mountain valley, far too modest for the leading city of Lycaonia.

\section{Divaz - Pinarkaya. A convincing new location for Thebasa.}

\section{General description and register of the monuments.}

G. Laminger-Pascher's reasoning was correct. Thebasa is indeed to be found in Taurus, at the crossroads, and near the castle. An additional essential criterion needs to be added: that of space able to accommodate and feed an agglomeration of people.

Pinarkaya meets all these conditions and more. It lies in the county (ilçe) of Ayranc1, and the province (il) of Karaman and was a hamlet of adjacent Büyükkoraş until 1952. It is located at an altitude of circa 1,580 meters, among fertile undulating fields, on the banks of a ravine with a stream that flows north to İbrala Çayı valley, some 600 meters away. It had 273 inhabitants in 2018. ${ }^{20}$ Until 1964 Pinarkaya was called Divaz.

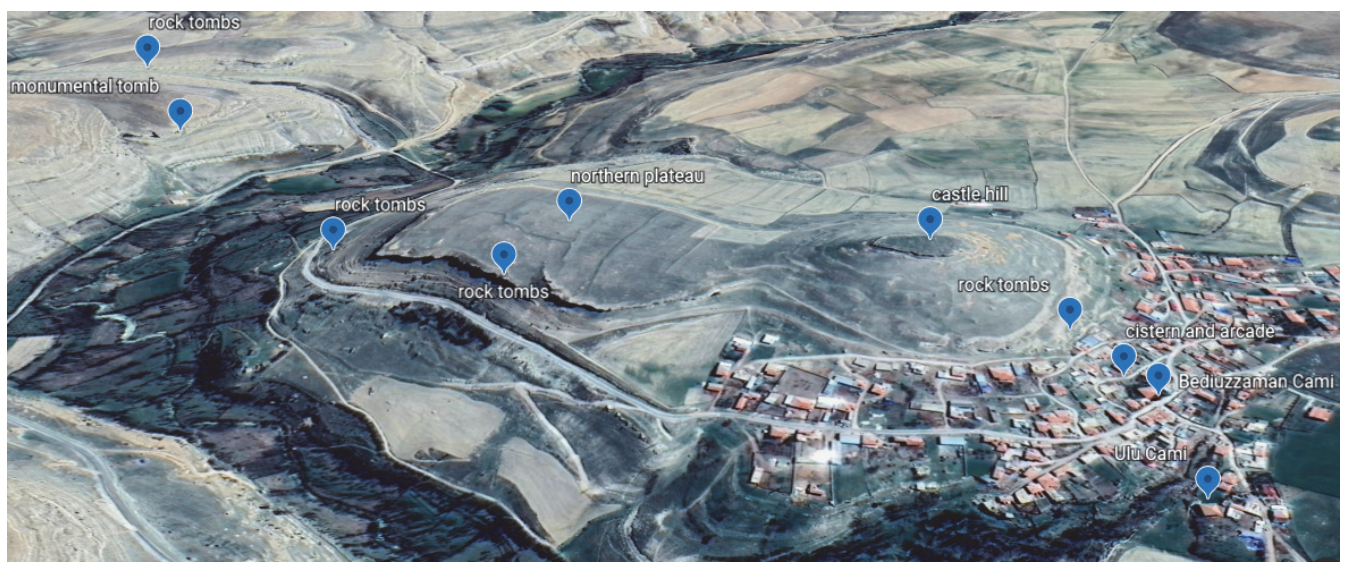

Map 2) Google Earth view of Divaz-Pınarkaya

There are number of noteworthy monuments here. Among them a "big" mosque (Ulu Camii), a three-nave, three-span rectangular hall with a wooden ceiling supported by four pillars (Fig. 1). It is made of limestone ashlar blocks of varied sizes, rather carelessly fitted, joints filled with pebbles. The stones bear traces of reuse, but with few exceptions lack individualizing features that could hint at their earlier use or provenance. A string of several ashlars resembling Ionic architrave can be seen in the west facade; the corner of the edifice on that side stands on a stepped plinth; bosses protrude from some ashlars. The entrance from the south has a lintel profiled on a wheel section; the small window above it is curtained with a tracery slab (transenna). There are two other windows on this side, and two narrow, vertical loopholes on the west. The austere interior is devoid of decoration, except for one of the pillars dressed with cylindrical, coarsely cut capital, ornamented with a row of eight up-pointing, veined leaves, intertwined with rosettes (Fig. 2). According to the residents' testimony, this building was originally a church.

${ }^{20}$ According to the 1950 census there were 550 inhabitants. 


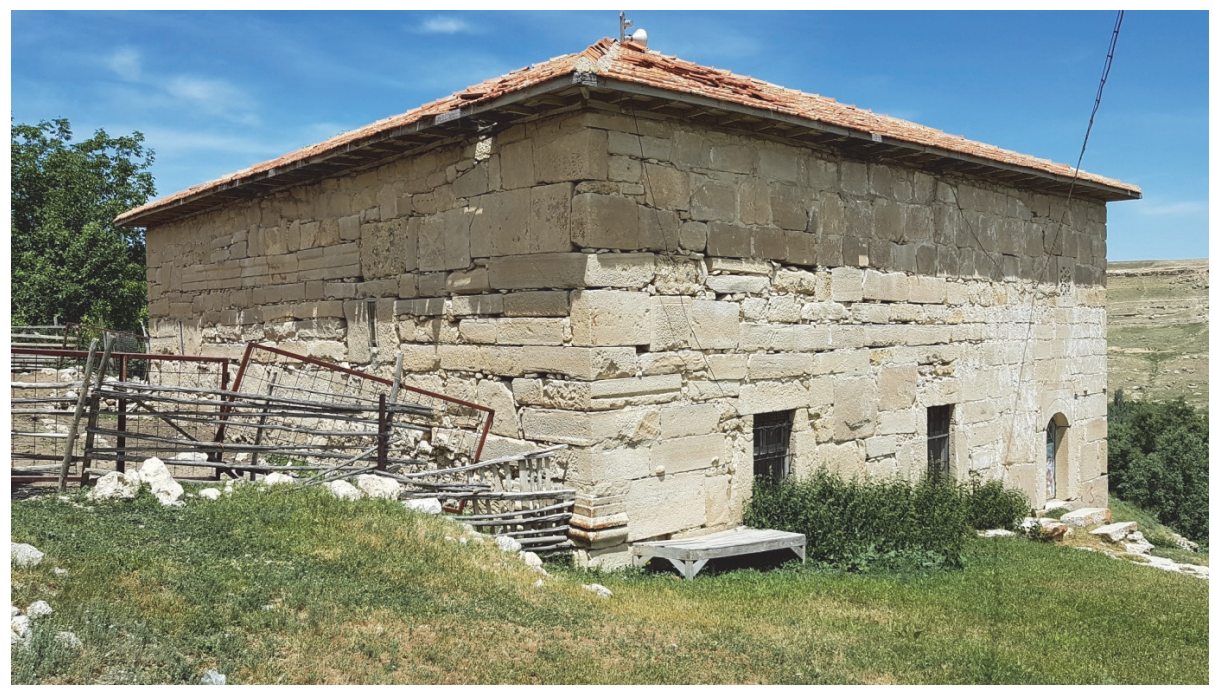

Fig. 1) Ulu Camii, exterior from southwest

The information plate on the second mosque (Bediüzzaman Camii) states that it was put into service in 1996, but there are various Byzantine spolia around and on neighboring plots, including capitals and sizeable flattened columns (Fig. 3-Fig. 4). ${ }^{21}$ Since the mosque is entirely plastered it is impossible to determine whether, and to what extent it was built from earlier remains. Only a part of a lintel with the sign of cross and an interlaced beam (probably piece of a templon) - project from the bottom of the staircase (Fig. 5-Fig. 6). The stonework is modest, but of high artistic quality.

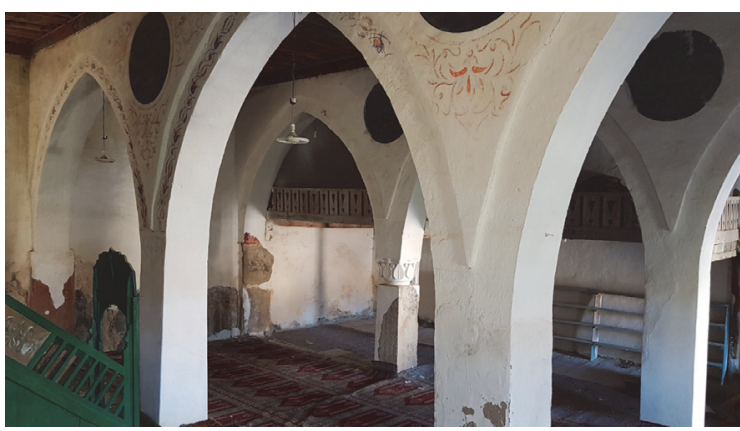

Fig. 2) Ulu Camii, interior from southwest

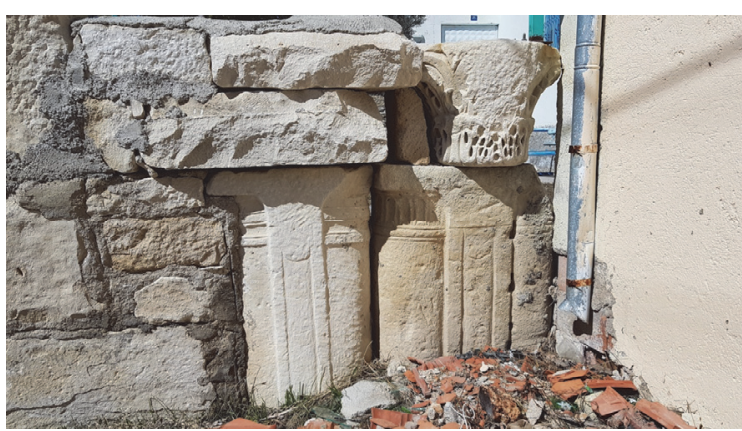

Fig. 4) Bediüzzaman Camii, courtyard

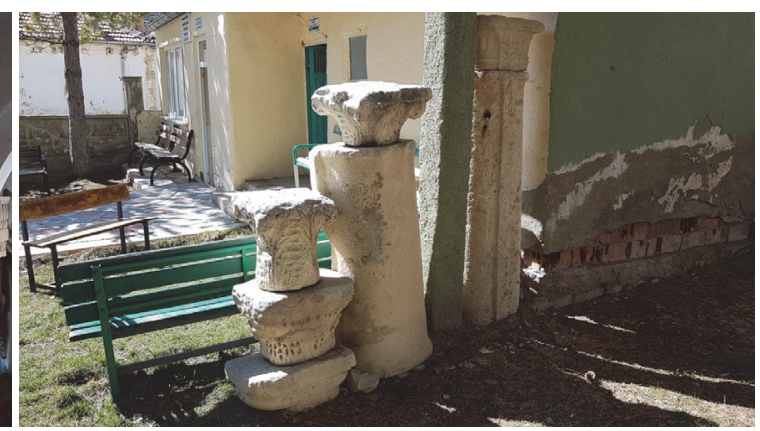

Fig. 3) Bediüzzaman Camii, courtyard

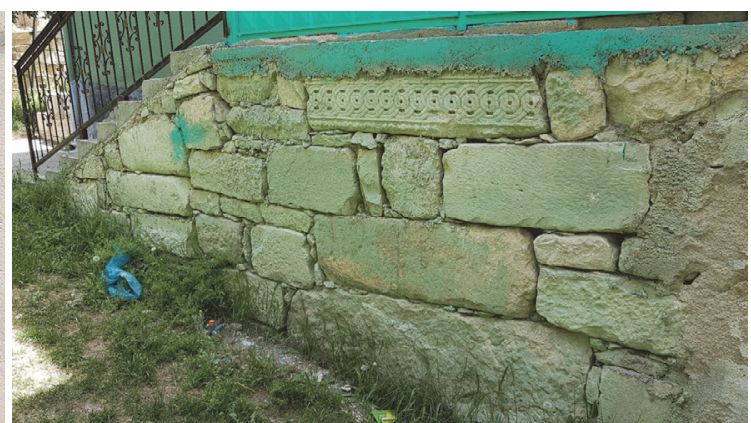

Fig. 5) Bediüzzaman Camii, staircase

${ }^{21}$ There is no satisfactory term for this element. Mullion is a window pillar, but the term is not applied to columns. The double column depicts closely spaced parallel elements sharing base and capital. So I allow myself to call it a "flattened column". 
At the back of the mosque, a wall rises 3 to 4 meters high, with a street running above it. The wall extends along a corridor leading to a barrel-vaulted cistern, 4 by 14 meters. It is assembled of smoothly dressed ashlars, without mortar. Distinguished by its professional workmanship it is still remarkably well preserved (Fig. 7). ${ }^{22}$

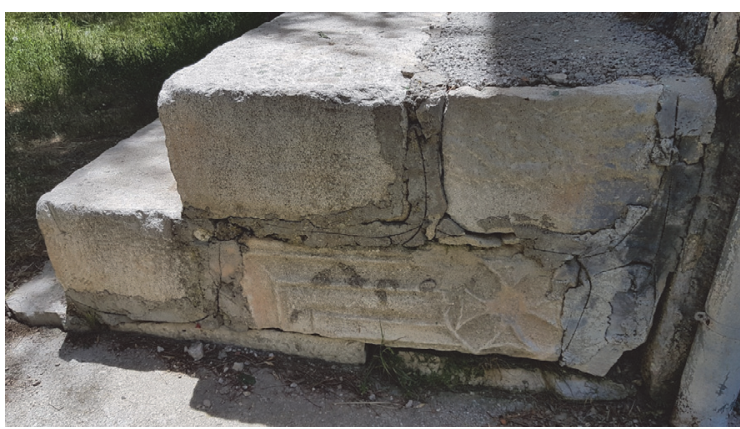

Fig. 6) Bediüzzaman Camii, staircase

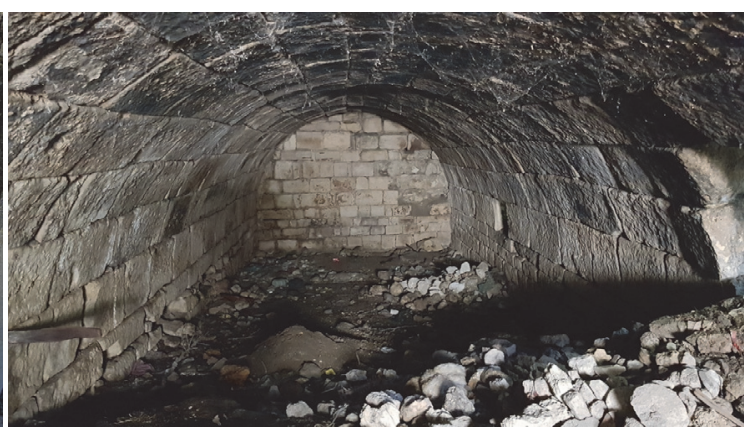

Fig. 7) Cistern, interior

Above the cistern, on the edge of the mosque's plot, there are also remains of an unspecified structure with a window and a semicircular arcade or arch (Fig. 8).

From a stylistic and technical point of view, this entire destroyed complex can be dated to the fifth-seventh century.

Spolia are ubiquitous. Pınarkaya's buildings are largely made from them, and they are richly distributed over a cemetery as well (Fig. 9-Fig. 10).

Among the most spectacular there are: lintels (Fig. 11), a pair of large jambs with refined moulding (Fig. 12), an elaborate templon base, countless pieces of entablature, columns etc. (Fig. 13). There are over a dozen of flattened columns, but it is impossible to count them accurately as some are broken in pieces. The largest ones are more than two meters high.

A hill of a peculiar shape, known to the local inhabitants as the kale, dominates the village: it is a truncated cone with slopes inclined at an angle of about 30 degrees (Fig. 14).

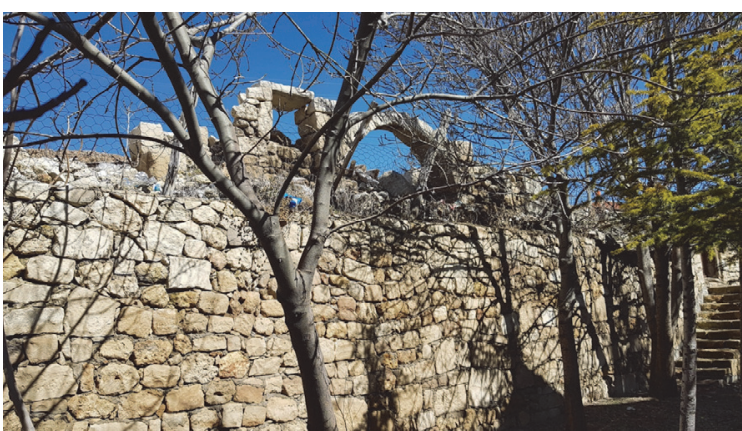

Fig. 8) Structure over the cistern, from a courtyard of Bediüzzaman Camii

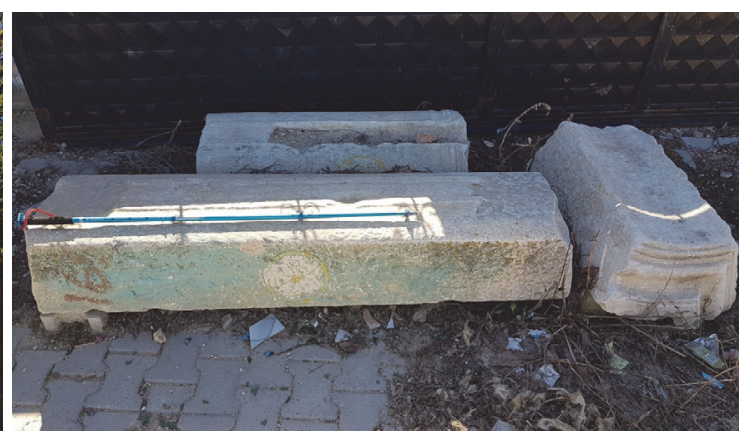

Fig. 9) Spolia by the graveyard gate

\footnotetext{
${ }^{22}$ In April 2019, the corridor was blocked by the partial collapse of the cistern's vault and it was not possible to open it despite the good will and genuine dedication of the Pinarkaya mayor himself. Trusting in the craftsmanship of the Byzantine stonemasons, I dared to enter from above, through a narrow crack created by damage.
} 


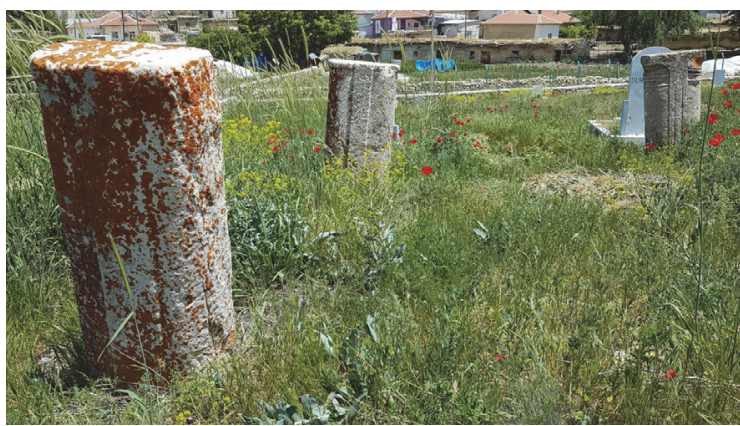

Fig. 10) Flattened columns at the graveyard

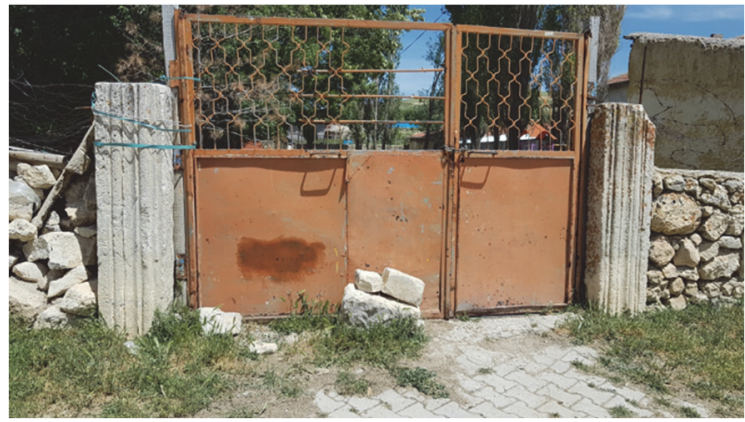

Fig. 12) Pair of jambs

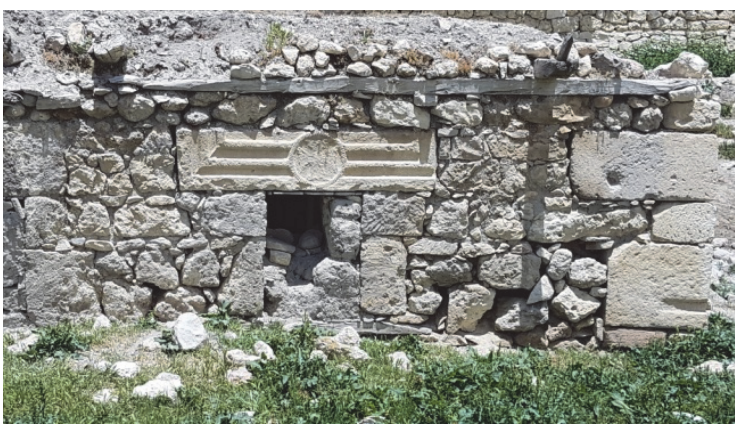

Fig. 11) Lintel (June 2019)

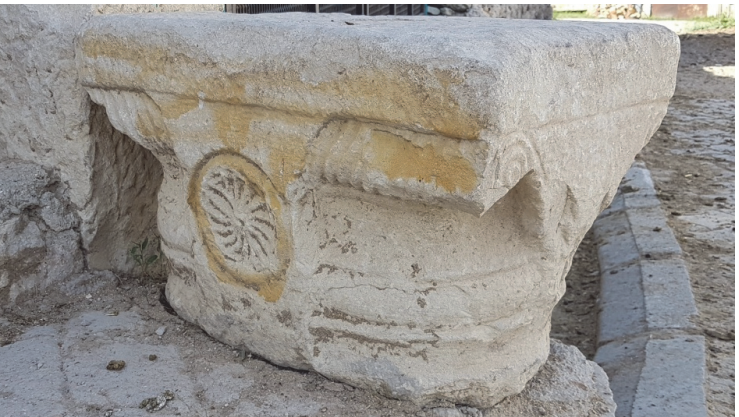

Fig. 13) Capital

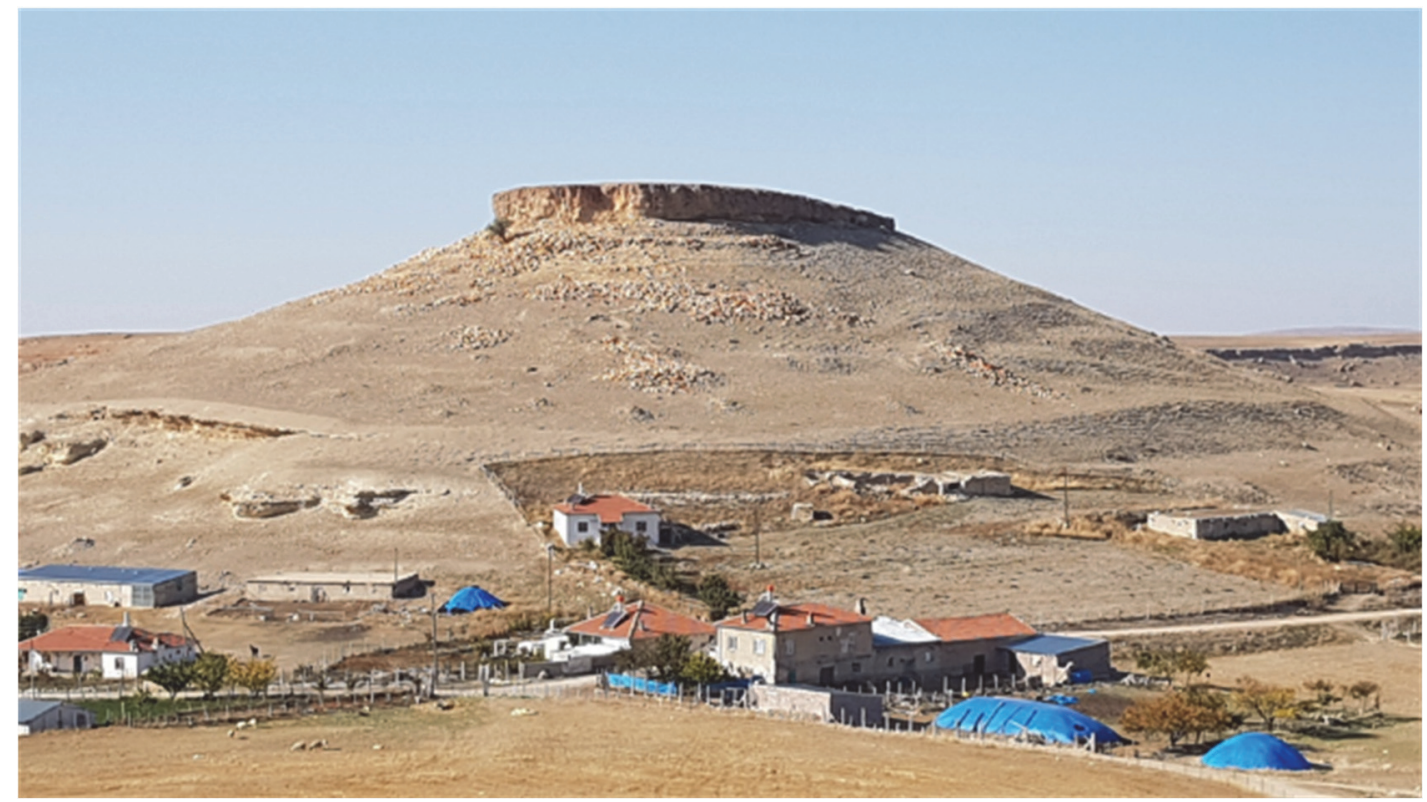

Fig. 14) Kale hill from south

The flat oval top, some 275 meters in circumference stands on a vertical and sometimes overhanging projection three to five meters high. Given the heavy erosion of the upper section of the hill, it can be assumed that the height difference was once greater. The periphery of the summit was surrounded by a wall, not extant today. One can get to the top through a rock-hewn gate about two meters wide (Fig. 15). ${ }^{23}$ Round holes of circa 1 meter diameter and rectangular pit of

${ }^{23}$ Access to the top of the castle hill is currently prohibited. In 2017 it was tightly wrapped in steel mesh by AFAD (governmental agency for disaster and emergency situations) due to falling rocks. It is possible to climb the mesh, (which is easiest to do from the eastside) but it is quite complicated and risky. 
circa 1,5 by 2 meters are cut out in the top surface; diverse ceramic material is widely available; debris from a larger structure can be seen in the southern part. It could have been a keep (Fig. $16)$.

Directly north of it lies a vast, even plateau with a circumference of about 1.25 kilometers and an area of some 10 hectares (Fig. 17).

Ceramic material and large heaps of pebbles testify to edifices once standing there. Though living conditions were tough due to the lack of water resources, and the plain is uninhabited nowadays, there must once have been a compact residential compound, especially in time of insecurity. This is a very safe setting - protected by steep cliffs from the west and north, a castle from the south, and, presumably, a wall from the east.

Although the actual ancient settlement seems to be buried under the contemporary village, it must have comprised the northern plateau as well as a number of other points around Pinarkaya. There are traces of settlements on two mounds south of the castle hill and elsewhere. There are also a number of rock-cut tombs around, particularly a row of about fifty burial chambers evenly hewn in the vertical western scarp of the northern plateau (Fig. 18a).

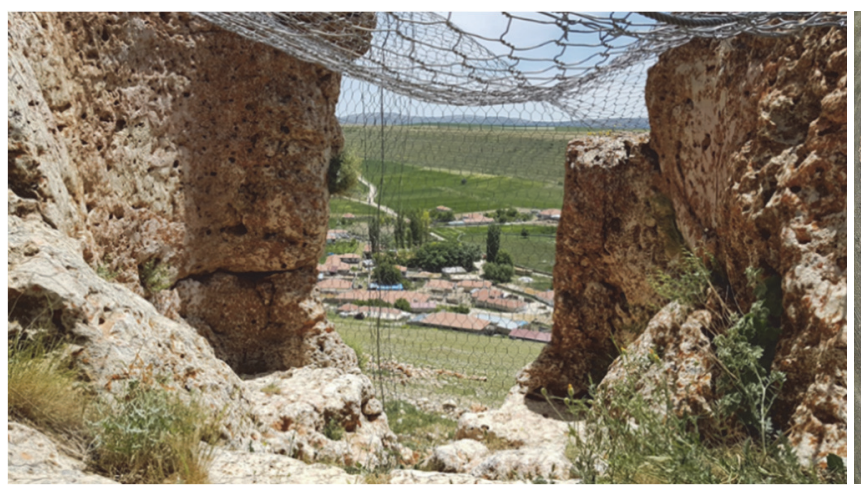

Fig. 15) Kale hill, gate to west

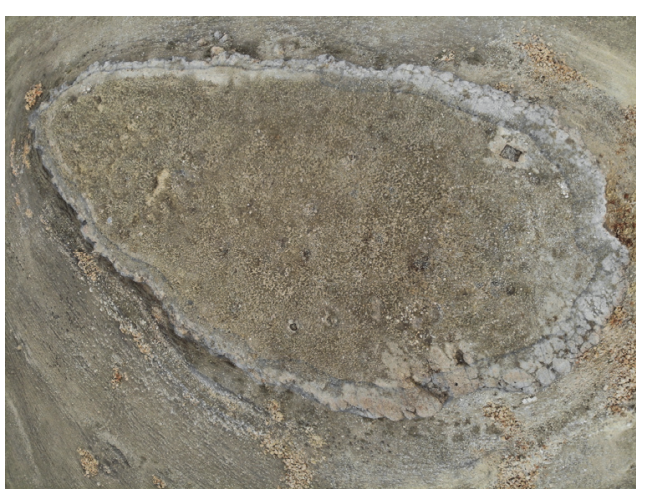

Fig. 16) Drone view of kale hill.

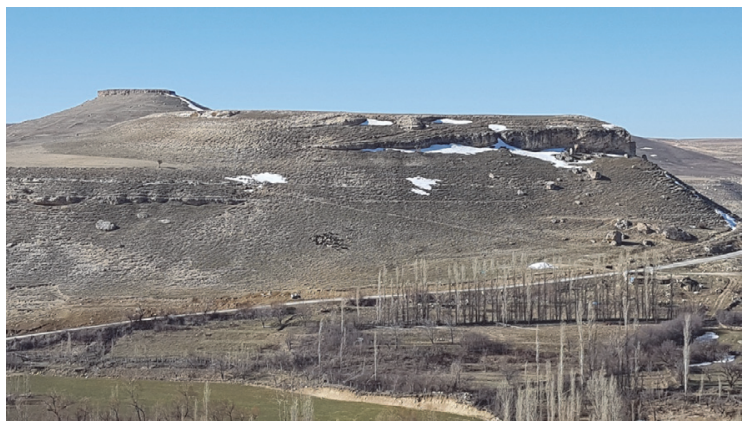

Fig. 17) Kale hill and the northern plateau from north east

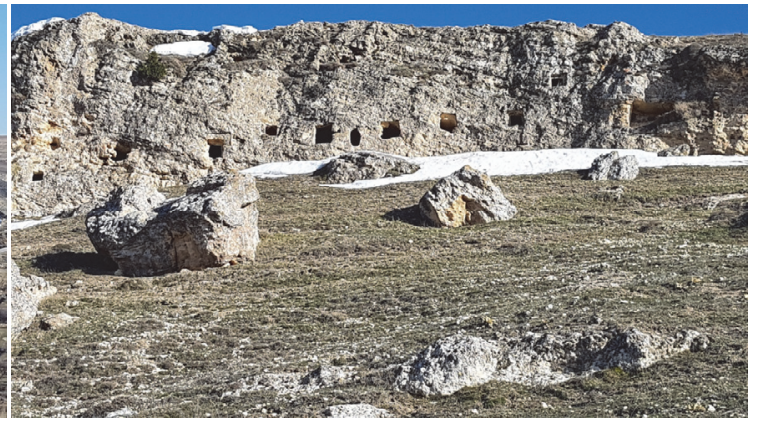

Fig. 18a) Tombs in the northwestern cliff of the northern plateau

The exact number is hard to estimate as some are heavily eroded. Furthermore, there are at least five groups of isolated rock graveyards in the vicinity consisting of a smaller number of tombs. The most spectacular of these is a monumental mausoleum with a badly damaged columnar portico in the İbrala Çayı valley, quite unprecedented in this area (Fig. 18b). By the river itself, there are remains of an old mill with scattered pieces of a big grinding stone. ${ }^{24} \mathrm{~A}$ site called

\footnotetext{
${ }^{24}$ Deeper south-east in this very valley, local residents reported a huge, four storey cave dwelling, that I was not able to explore.
} 
Pınarkaya Örenyeri, more than two kilometers west of the village deserves special attention. It lies on a gentle hill among mildly folded foothills, intensively exploited for agriculture, in the fork between two gorges watered by springs, that converge into one, heading north to İbrala Çayı valley. The center of the settlement has the shape of an irregular pentagon with a circumference of about 900 meters and area of about 5.5 hectares, reflecting the geomorphological relief of the rock on which it was situated. Piles of irregular stones and an organized pattern of pathways/streets are visible. There are no surface remains of ceramic material or worked stones.

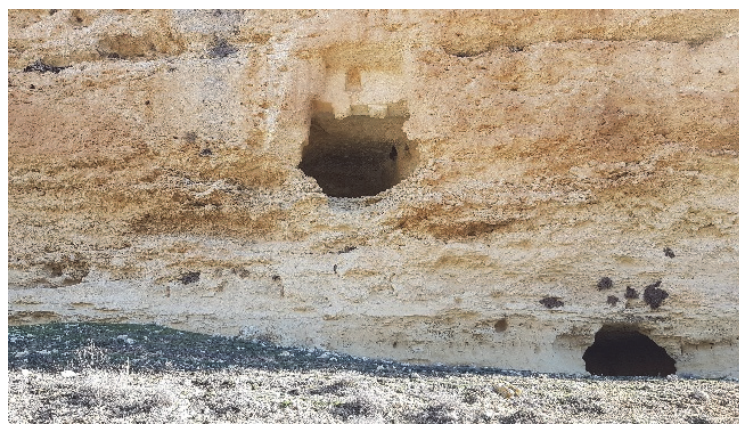

Fig. 18b) Monumental mausoleum

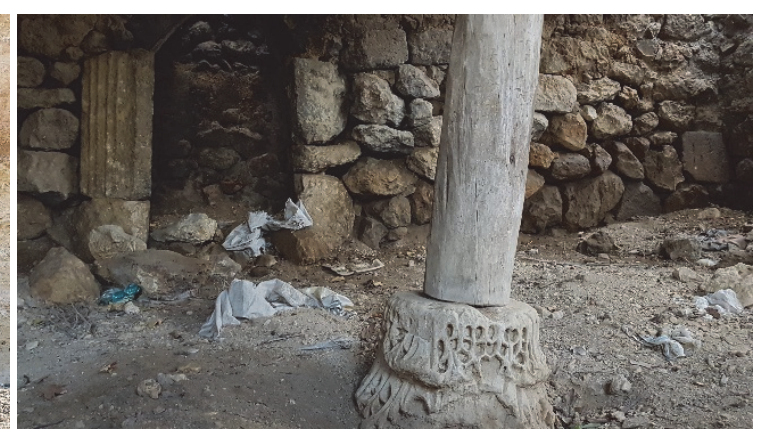

Fig. 18c) Spolia at Gözlek-İncesu

These remains indicate that there was a major population center and a military base in Pinarkaya. The identification with Thebasa is supported by the following arguments:

- It was located even deeper into the Taurus range than Divle, conforming with the evidence of Pliny.

- Although it lay off the Ereğli - Karaman road, it was at the intersection of important routes from and to Cilicia, leading towards Korykos and Tarsus.

- It controlled extensive agricultural land, abundantly supplied with water, able to feed a large community.

- It had a castle hill with remains of fortifications.

- Numerous spolia in the village have survived from a large church or churches.

- Remains of other Byzantine structures including a large vaulted cistern.

- There are traces of ancient settlements, especially one called Örenyeri, as well as numerous rock necropoleis, including one with a monumental tomb.

- The earlier name of Pinarkaya was Divaz, which conspicuously resembles and must be derived from ancient Thebasa. ${ }^{25}$

\section{Monuments versus notes - an attempt to interpret the site through the prism of historical sources}

Let us now focus this picture in the light of the historical records. The illumination will cast a narrow beam, but maybe sufficient to bring some vague contours of events out of the darkness.

The castle could easily accommodate some hundreds of people, with another few hundreds on the northern plateau. The containers carved in the rock are now cluttered with debris, so it is hard to assess their volume, but they do not look very capacious. They provide storage for dry provisions rather than liquids, and we should recall that scarcity of water contributed to Thebasa's fall to the Arabs in 793. The edge of the castle hill was encircled with a wall, but it lacked

\footnotetext{
${ }^{25}$ Similarly: Sebastia became Sivas.
} 
solid fortifications. The same can be said about the northern plateau. The site could successfully resist a band of plunderers, but when armies with siege machines arrived, the defenders did not have much chance. Ralph J. Lilie claimed that the sieges of Thebasa was a long-lasting enterprise, adding that in 793 the crew was dying of "hunger and thirst." This view is not justified by sources, since Michael the Syrian mentioned only the lack of water. Conditions described above demonstrate first and foremost that Thebasa was poorly equipped for defense and this was the principal reason why it fell into enemy hands relatively frequently. ${ }^{26}$

There are strong indications that Bediüzzaman Camii was erected on the site of a church - presumably the episcopal one. The spolia recorded here must have belonged to a large building, probably a basilica, as indicated by a number of large flattened columns. In Byzantine architecture, they function mainly as mullions, but in the churches of Binbirkilise, they serve as internave supports as well. At least eleven elements of this kind in Pinarkaya are over 2 meters high, suggesting their similar role here. Voussoirs are rare, so either the edifice was not vaulted or these are still hidden in the walls of modern houses. Another thing is that flattened columns are of at least three different sizes and show some stylistic variation. They may thus originate from another ecclesiastical structure, maybe once standing on the northern plateau. Local residents firmly point to this area as a source of building material for the village.

It is unresolved whether the arch/arcade and the cistern constitute the remains of this hypothetical cathedral or of some other facility (episcopal palace?). A specialized investigation might be able to answer this question. The complex was established before the Arab invasions and it might have been destroyed over the course of these.

The foundation of another church - today's Ulu Camii - can be explained by population growth, possibly after the Byzantine reconquest of Cilicia. The church foundation could perhaps date to the turn of the tenth / eleventh century, but the defensive features of the edifice may point to an earlier period, when Tarsus was embraced by the Hamdanids in the $9^{\text {th }}$ century, who no longer organized inroads further west against the Byzantines, or to even earlier times. Similar churches stand in nearby Büyükkoraş and Kayaönü. Their foundation could argue in favor of some coordinated colonization. ${ }^{27}$

It is known that on the occasion of Theophilos II's military reforms in the 840s, units of two thousand Khurramites from the disbanded Persian corps, were assigned to each theme. Wherever it was feasible, these soldiers were garrisoned close to the frontiers. Thebasa belonged to Anatolikon, which, as a result of the reforms, lost a substantial part of its borderland, which was subsequently attached to new kleisoura of Seleucia. It is not possible to retrace the course of borderlines accurately, but it seems that Anatolikon retained only a scrap of this critical area, but one of a great importance: the little-frequented mountain defiles leading to Tarsus. ${ }^{28}$ After

\footnotetext{
${ }^{26}$ Lilie 1996, 177, 192.

${ }^{27}$ Local residents claim these buildings were originally churches though I have an impression they were rather built on church sites anew, within old walls at most. The same pertains to the kilise-camii at Örenliyurt described below.

${ }^{28}$ On Treadgold's maps Anatolikon was positioned away from the border. It should be noted however that it was far more logical to control the abovementioned Tarsus defile from Anatolikon, than from Se-
} 
the reform, about one thousand Khurramites were directed to the Lycaonian part of the theme. If they were to protect the boundary, Thebasa would be the most appropriate spot for a garrison. Building churches would have had additional justification, since they were all converts to Christianity.

About 900 Hyde disappears from Notitiae Episcopatuum and Thebasa reappears. Hyde, set in the plain, must have ceased to exist long before (Sidamaria likewise), but this was decreed only on the occasion of the subsequent ecclesiastic reorganization.

The material from which Ulu Cami was erected is a topic for itself. The ashlars clearly differ in style and processing from the "cathedral" ones. They may have come from the tombs and temples of pagan Thebasa. The question persists whether they originate from Örenyeri which is relatively close to this edifice. ${ }^{29}$ Against this background, the relation between Pinarkaya Örenyeri and Pinarkaya is worth studying. The former seems to have been abandoned long before the latter. This could have resulted from calamities of 536-542, "The Plague of Justinian" in particular, or, since it rests among gentle hills rather far from the majestic shadow of the castle, it may simply have been vulnerable to attack during the Roman-Persian war at the beginning of the seventh century, or from later Arab raids.

Otherwise linking both centers might be a false trail. The area was quite densely populated. Büyükkoraş with its church is just over one kilometer from Pınarkaya. Örenyeri could have been an anonymous satellite estate. Such an option would also be in line with the already referred to process of militarization or incastellamento - a transformation during which settlements which lacked refuges were abandoned. The distance of two and a half kilometers that separates Örenyeri from the castle gate could have been too much to escape a pack of fast-paced brigands, especially because there is no watchtower in vicinity, that could have provided warning of impending danger well in advance.

\section{The empire strikes back}

The fall of Thebasa in 793 was recorded by Theophanes, Tabari and Michael the Syrian. R. Lilie notes this as a rare occasion when Greek, Arab and Syriac sources confirm one another. ${ }^{30}$ Over the next several years, Thebasa was to attract the attention not only of chroniclers but of rulers as well.

What happened that the city, forgotten since Pliny's time, returned to the pages of history? Ramsay claimed it was because of the situation on the "big road". Now, that its "out of the way" and remote location is revealed, we can see different reasons for its increased importance in the middle Byzantine period. Thanks to its secluded position Thebasa was able to avoid the devastating effects of the long-range invasions of the Umayyad period. Sheltered by the chains of the Taurus and its own castle, connected to the coast that remained in Byzantine hands, surrounded

leucia - as the maps imply. Treadgold 1988, 344, 376. The roads over Taurus are tentatively described below.

${ }^{29}$ The bosses on some of the ashlars are puzzling. After completion of the work these were generally removed. Apart from of the generally harsh nature of the edifice, their presence gives reason to wonder whether they came here as spolia, or straight from the quarry.

${ }^{30}$ Lilie 1976, 164. 
by fields and pastures, Thebasa managed to survive until the middle of the eighth century, when the Empire began to regain its strength and proceeded to offensive measures.

At the turn of the eighth and ninth centuries, there was an intensification in the military activity of the Empire, which began to cope better with Arab attacks and even fight back. The Abbasids responded to this by organizing extensive military interventions. This became quite a pattern: for example, in the years 778-82, after a series of Byzantine thrusts, Muslims mobilized a huge army headed by the young Harun ar-Rashid. Despite all the efforts of his army, which was almost twice as large as the opposing forces in Asia Minor, the campaign proceeded with mixed fortunes and was successful only by accident, thanks to the defection of the Armenian-Byzantine commander Tatzates' to the forces of the Caliph. During its course, Muslims failed to take any key center, and inflicted little damage on the Empire, except for the obligation to pay a high tribute.

The 806 campaign was similar. It was a reaction to the capture of Tarsus by Nikephoros. The largest army in the history of the wars with Byzantium led by Harun still achieved no spectacular victories either. Prisoners were taken and several forts, including Heraclea (identified as Tont Kalesi near today's Ereğli), a stronghold of questionable significance. Nikephoros agreed to pay a tribute, but a much lower one than his predecessors. Then he quickly gave up paying and started repairing the demolished castles. This triggered punitive expeditions by the Arab forces, but on a much smaller scale, and ended up in a peace treaty of 808 .

Most historians assess the military and political outcomes of Harun's wars rather critically, emphasizing their self-promotion and religious propaganda aspects. ${ }^{31}$ This mainly pertains to the events of 806. But this campaign does not look so unproductive at all. Entering upland Anatolia with a gigantic army and initiating works on the residential compound in Tyana, the caliph showed his immeasurable power and readiness to consolidate in Cappadocia. It was not without a reason that peace negotiations were held in Tyana. The imperial emissaries had several times seen their opponents' large armies and were maybe not so impressed by them, but this time they saw an army of masons - and this could have been alarming. The establishment of a permanent base in Tyana would pose a deadly threat to Byzantium.

But the most momentous military outcome of this campaign was the devastation of the Byzantine base intended for retaliative actions. ${ }^{32}$

The quarter-century-long struggle that Harun waged against the Empire, made him aware of its rising potential. He fortified Tarsus in 787, concerned that the Byzantines would overrun it, and

\footnotetext{
${ }^{31}$ Michael Bonner best summarized these views: "The energy and resources which Harun al-Rashid devoted to his apparently futile Byzantine wars have puzzled historians. In the eyes of some, it was Harun's conception of his duty as head of the community which led him to concentrate on the jihad, as well as on the pilgrimage, alternating the two year by year. Others see Harun's war effort as "propaganda for internal consumption." For yet others, these were real wars of conquest, and the disparity between effort and result may be attributed to "difficulties of supply and the harshness of the weather." But not only did the war achieve few concrete gains; real activity in the frontier district, as measured in buildings, fortifications, raising of armies, and organization of supply networks, did not actually increase much, if at all. What was new was the caliph's personal involvement in the jihad". Bonner 1996, 99.

${ }^{32}$ Haldon - Kennedy 1980, 114-115; Treadgold 1988, 146.
} 
acted likewise in 807. Though Nikephoros had been defeated and humiliated just a year earlier, Harun feared that the emperor would return to a deserted Tarsus. For this reason, he decided to redirect a body of troops (originally commissioned for a military raid) to recolonize the city. It should not be overlooked that at that time the caliph faced severe internal troubles that drove him to Khorasan. Under these circumstances, his priority became to curb Empire's offensive capabilities and strengthen his own border infrastructure. There is no reason to believe that Harun was interested in territorial gains beyond the Taurus. Such acquisitions would involve huge costs, with rather minor profits. Generally, the Abbasids had enough trouble maintaining the integrity of their enormous, populous, prosperous and bursting at the seams superpower, without taking the risk of enlarging it with inhospitable highlands inhabited by hostile folk. Besides, they had no interest in provoking Constantinople and stimulating its belligerent reaction.

From this perspective, the caliph's efforts of 806-07 proved quite successful: Nikephoros decisively withdrew from the East and focused on the Balkans. Even Harun's death did not make him return to this theater. Apart from the emperor's current involvement in the West, it is not known what stood behind this stance: whether it was a lesson given by the colossal army of soldiers (and masons) at Tyana, or rather the lack of a base for potentially offensive maneuvers. Peace prevailed here so uninterruptedly that even amid the troubles of the Fourth Fitna (civil war in the Caliphate 811-830), permanently threatened Cilicia became "a haven of peace and quiet". And in 831, when hostilities resumed, they followed the already established pattern Theophilos took Tarsus, and Al Mamun retaliated by capturing Heraclea.

The events concerning Thebasa mirror the larger history: in 791, Constantine VI set out against Cilicia, but his campaign miscarried somewhere in Lycaonia, due to the weather conditions. In 793, the Muslims organized an expedition that targeted Thebasa. A similar sequence occurred in 805: Nikephoros I ordered renovation of Thebasa, then invaded Cilicia and seized Tarsus. In response, Harun demolished the fortress, obliging the emperor not to rebuild it. But Nikephoros did not keep his word, a decision which produced yet another restoration of Thebasa and its subsequent capture. So here we are dealing with a similar exchange of blows, as occurred in the wider arena. And here too the impression persists that the actions of the Muslim forces were of a retaliatory and preventive nature. They did not perceive Thebasa - it seems - as a mere refuge and observation post, but as a qualitatively new, aggressive phenomenon that had to be neutralized at all costs.

That Thebasa could generate threats follows from an analysis of historic accounts as well: Theophanes reported that in 793 the fortress capitulated "...on terms. Because of that, they freed its officers to be conveyed back to their own country." Michael the Syrian added that Muslims seized "gold and valuables" upon its surrender. A rather suggestive image emerges from these laconic references. Thebasa does not seem to be only a shelter for farmers and their livestock, like the surrounding "cave castles". There are officers here, rather than local people, who are to be sent "to their own country." The demise of four hundred defenders is meaningful too. There was not enough of water, as there were no proper receptacles. But since refuges were designed for a definite number of individuals, it suggests that there must have been an excessive concentration of people at that time equipped with "gold and valuables". The northern plateau beyond the castle, with its defensive qualities, could have had something to do with the stationing of troops as well. 
Interesting conclusions can also be drawn from the way Theophanes represents the events of the year 806. He enumerates four castles that fell to the caliph then and continues: "But after the Arabs retired, Nikephoros immediately rebuilt and fortified these fortresses. When Harun learned this, he sent out a force which took Thebasa." Thebasa was not picked out by accident. It is already quite intelligible why the caliph consistently returned with a force to destroy it. What may seem peculiar is the relative ease and frequency with which he performed this task. The explanation to this has been partially given: the castle had neither water reservoirs nor major fortifications and could not be defended for a long period. On the other hand, due to its unique positioning - on a natural rock "island" that could not be leveled - it was quite easy to rehabilitate. Thebasa was not a kastron, a castle in the stricter sense, but rather an aplekton - a logistic point for concentration of troops and supplies. The aforementioned road to Tarsus furtherly enhanced its significance. The main way led through Cilician Gates. But along with the intensification and diversification of military activities, other defiles were used to a greater degree. They were harder to pass, not suitable for larger armies, but at the same time less well protected, exposed to surprise attack, and the securing of alternative exit routes. These tactics were specially favored by the Byzantines who controlled the Taurus but could not afford costly expeditions.

It is possible that in 793 troops were gathering in Thebasa to assault Cilicia, but Muslims thwarted these designs. Similarly, the army that took Tarsus in 805 might have set off from Thebasa, and a fact that the first ever exchange of prisoners of war occurred in 806 on the river Lamos (the next exchange in 808 also occurred there) was deliberate. We already know that Byzantines detained a number of Tarsiotes in 805, whereas Arabs could have held some Thebaseni. The banks of the Lamos were equi-distant from each place.

Thebasa's return to the history illustrates and provides testimony to the changes in balance of power between the Empire and the Caliphate at the turn of the eight / ninth century. The tendency to diminish the achievements of Harun's expeditions is often accompanied by underestimating the vitality of the Empire. In this context Thebasa's role has also been played down. ${ }^{33}$ The perspective outlined above manifests the offensive nature of Byzantine investment in border infrastructure. Thebasa's reincarnation as a base for Byzantine incursions provoked fierce repressive and preventive attacks by the Muslims. The demolition of Thebasa and similar hazardous points, breaking the switchblade, was a great success for Muslims. It hampered the expansive dynamics of the Empire and delayed the loss of Cilicia by a century and a half. ${ }^{34}$

\section{A look at the Taurus passes}

The localization of Thebasa throws a new light on the communication system through the Taurus. For it seems that the city drew its eminence mainly from its links with Cilicia. Brief exploration carried out in autumn 2020 proved a number of interconnected, affluent settlements on either side of the mountains, mostly unknown to the academic world. Since the deep valley of Lamos used to exercise a separating role - both geographically and historically - I have divided them tentatively into two groups: the western, "right-bank cluster" that led towards Olba/Diokaisareia and Corycus, and the eastern, "left-bank cluster" - towards Soloi/Pompeiopolis and Tarsus.

\footnotetext{
${ }^{33}$ Rott calls it dismissively a Troglodytendorf. Rott 1908, 115; Canard 1962, 378; Shaban 1976, 38.

${ }^{34}$ Treadgold 1997, 139.
} 


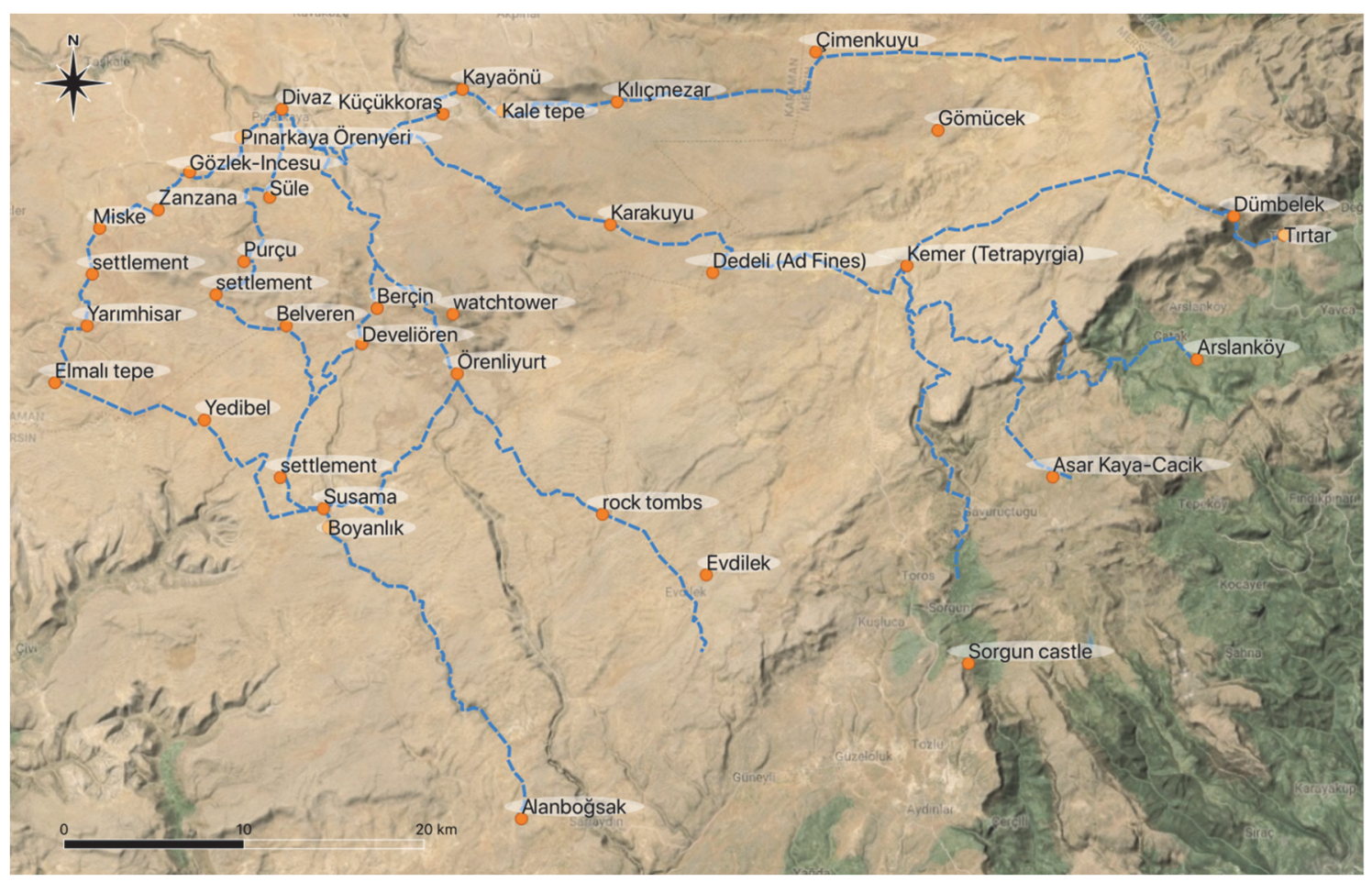

Map 3) Taurus passes (Google Terrain/ESRI Satellite compiled by M. Kamieniak)

The major route of the right-bank ran as follows:

- Pinarkaya Örenyeri.

- Gözlek kalesi - a partially fortified settlement with a church by today's Incesu cave (Fig. 18c).

- Zanzana - with a large pre-Byzantine tomb and a church (Fig. 19-Fig. 20).

- Miske Örenyeri - small town with a castle (Fig. 21-Fig. 22).

- Yarımhisar - castle and cave necropolis ${ }^{35}$ (Fig. 23).

- Elmalı kalesi - large tepe by a abundant source of apparently healing water (Şifalı Suyu) where it joined the route from Karaman. ${ }^{36}$

Further east there is a good, beaten track via Berçin yaylası (settlement) and Develi Ören (settlement with a church). ${ }^{37}$

${ }^{35}$ For the above mentioned sites see also: Bahar 2007, 241-242 (with precise coordinates).

${ }^{36}$ To my knowledge, this road was first mentioned by Hamilton. According to the information he obtained in Karaman, it ran as follows: Karaman - Kizil Chesméh (probably Çimenkuyu by Karaman) Alan Búzúk (probably Alanboğsak some $3 \mathrm{~km}$ north of Mağara) - Mezetli. Hamilton 1842, 322-323. Ainsworth suspected this to be the road taken by Menon escorting Epyaxa to Cilicia. Ainsworth 1875, 276. The major pass of this route is often called Yedi Bel. See: Mutafian 1988, 287.

${ }^{37}$ Berçin must be Perchin as mentioned by Hogarth, who made this road in 1890: "Perchin Bel, the watershed between the Plains and the Mediterranean." Pınarkaya residents take it nowadays as a principal road towards Silifke, though it is closed in winter. Hogarth - Munro 1893, 15. 


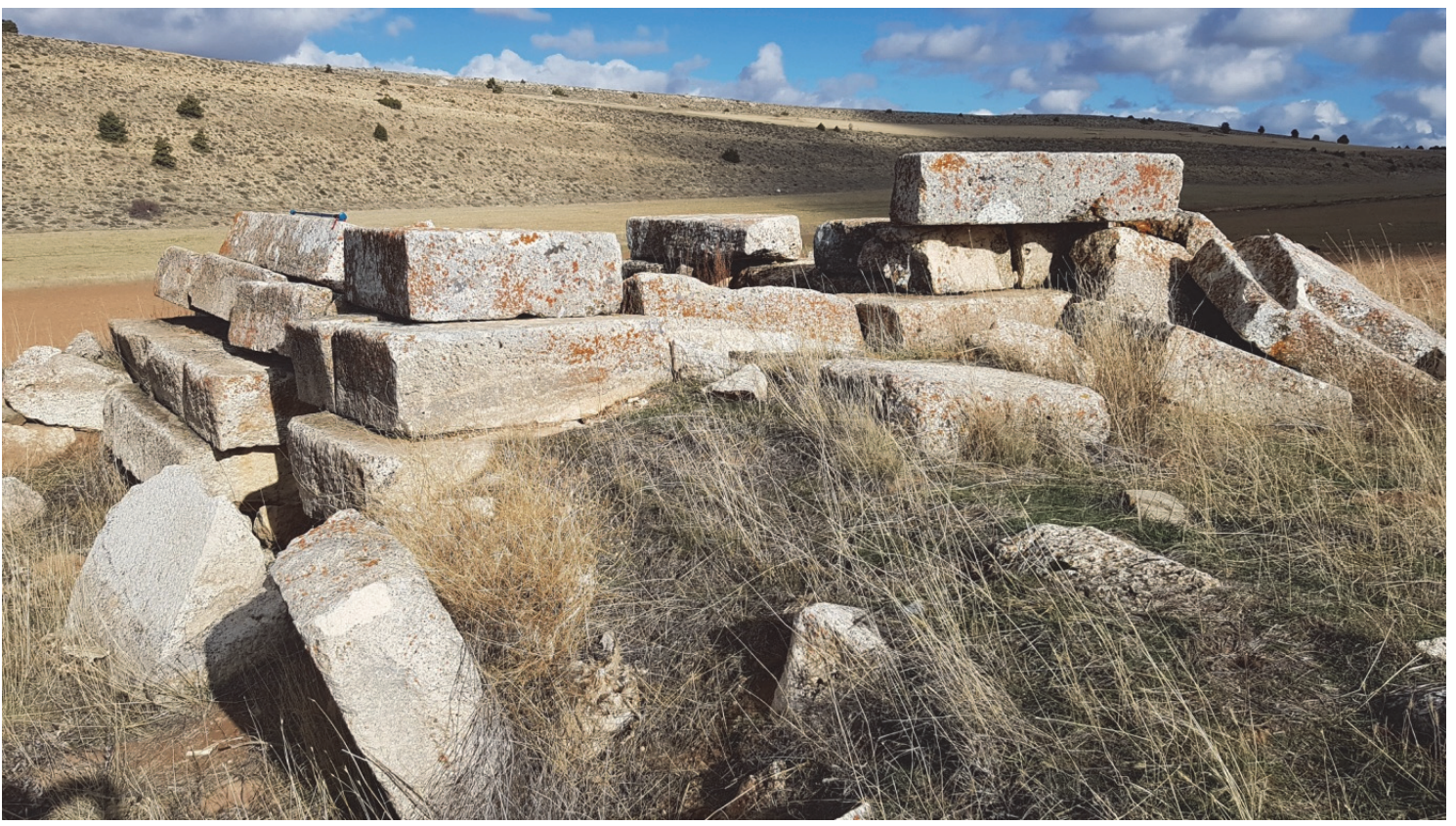

Fig. 19) Zanzana, tomb from south

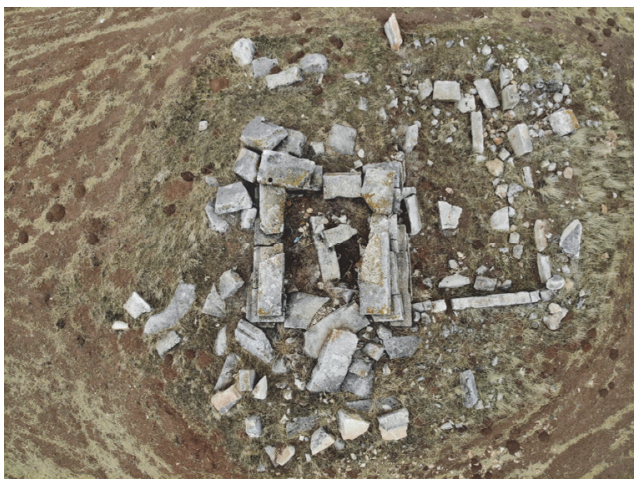

Fig. 20) Zanzana, tomb, drone view

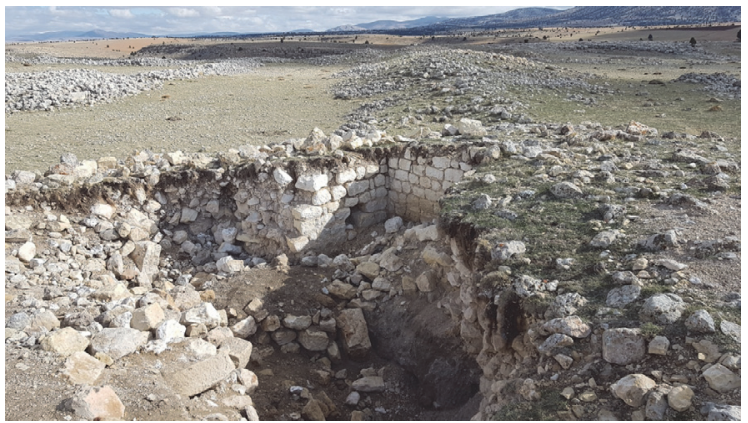

Fig. 22) Miske, castle from west

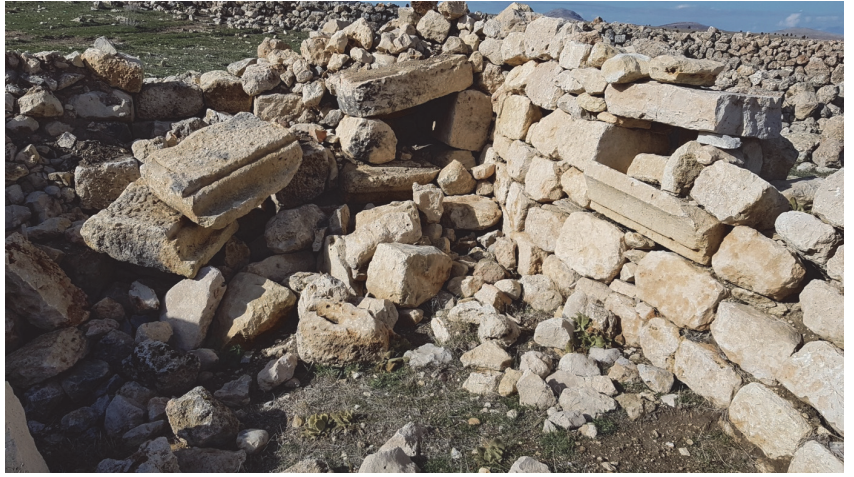

Fig. 21) Miske

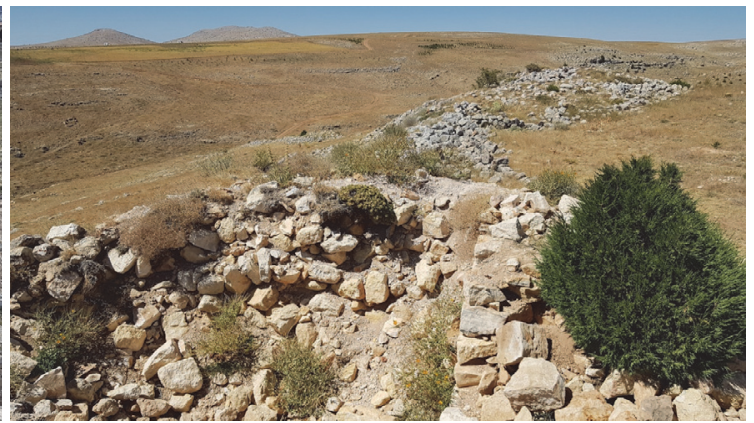

Fig. 23) Yarımhisar, castle 


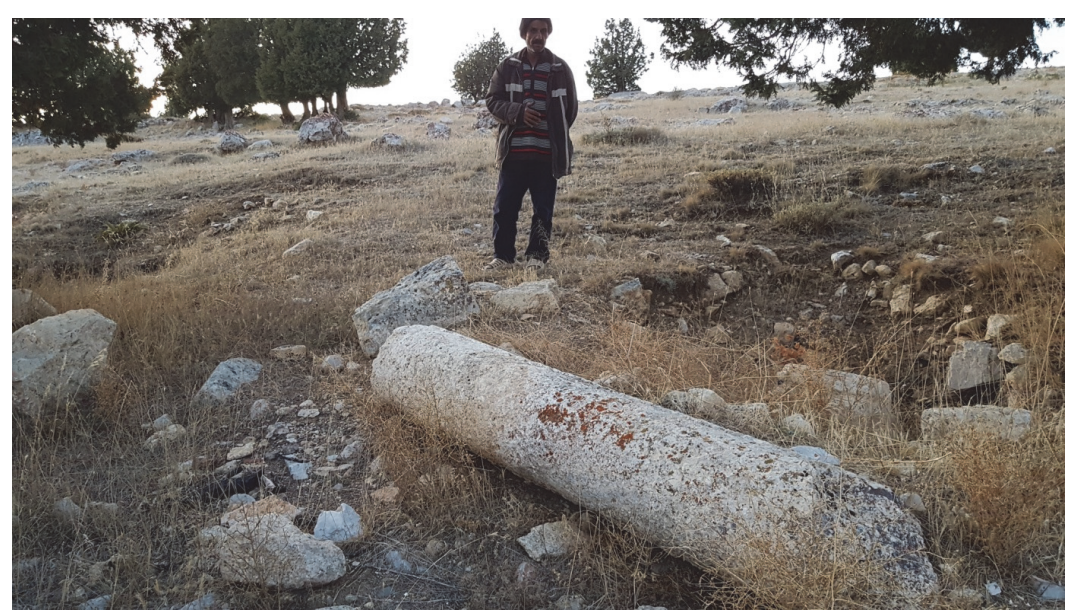

Fig. 24) My guide and friend Ali at Purçu kilisesi

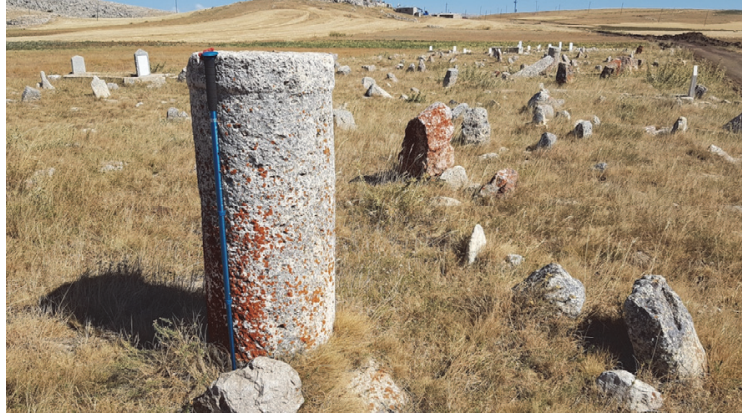

Fig. 25) Belveren, spolia at the graveyard

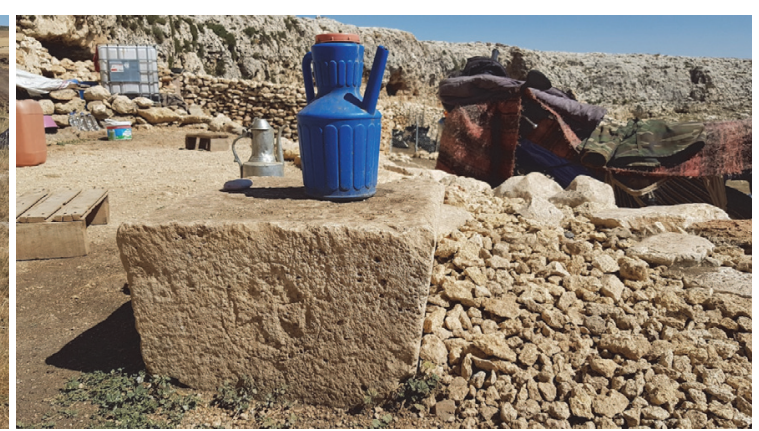

Fig. 26) Belveren, keystone

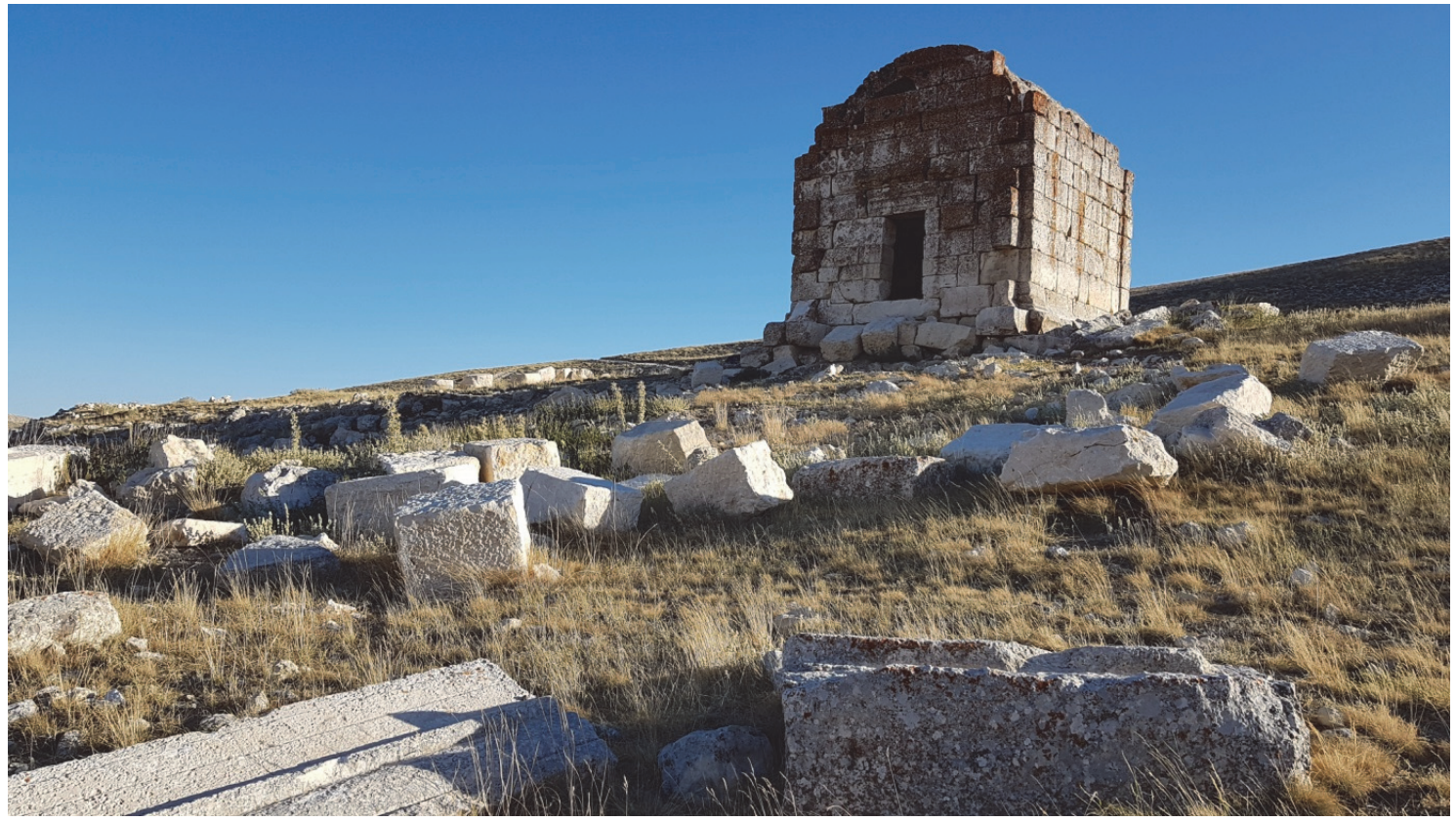

Fig. 27) Susama, tomb from northeast

Between these two there was another trail. It is not in use anymore, but must have been of some importance once, since there are at least three settlements along it, within a distance of around 7 km. Two of them had churches - Süle kilisesi and Purçu kilisesi (Fig. 24). The third one - unidentified by name - lies further south. In this settlement I have located a number of middle Byzantine construction elements in wrecked houses and in a local graveyard. Some of ashlars were 
slightly curved as if stemming from a vaulting or an apse. Otherwise, extant spolia bore no evidence of their supposed ecclesiastic provenance, so they might have been originating from some other structure, a villa rustica for example. ${ }^{38}$

These three routes depart from Pinarkaya and come together in Belveren yaylası (church) (Fig. 25-Fig. 26) near Özboynuinceli in Mersin province, around $45 \mathrm{~km}$ north of Mağara-Kırobası. ${ }^{39}$ South of it lies Susama which must have been a significant hub on the Cilician side with its monumental house tomb (Fig. 27-Fig. 28), temple (Fig. 29) and a military outpost of which not much remains (Boyanlık kalesi). ${ }^{40}$

As for the "left-bank cluster", first there is a route via Örenliyurt (quite a large settlement at the source of Lamos river with a church allegedly turned into mosque and a watchtower atop a mountain). From Örenliyurt one could still get to Susama or follow to Evdilek (number of cave dwellings including a natural, amphitheatrical grotto of gigantic size) and Avgadi-Aydınlar so it must have been quite an important spot too. ${ }^{41}$

Next to it, we have a modern highway Ayranc1 - Pinarkaya - Erdemli, passing close to ancient settlements at Karakuyu yaylas ${ }^{42}$, Dedeli yaylası (identified as Ad Fines) ${ }^{43}$ and Kemer yaylası (identified as Tetrapyrgia) ${ }^{44}$ from where one could proceed in three directions at least: towards Sorgun ${ }^{45}$, Arslanköy ${ }^{46}$ or via Dümbelek pass to Tırtar. ${ }^{47}$

Further east, there is a beaten earth road towards Dümbelek Pass via Küçükkoraş. The modern road ascends steeply in Kayaönü via Akpınar to Çatköy and traverses an arid, rocky plateau. In ancient times however, a parallel road on a southern side of small mountain range, was rather in

${ }^{38}$ With a sturdy car, I could barely cross a small mountain range between this anonymous settlement and Purçu kilisesi. Otherwise all the passes mentioned above and below are still in active (seasonal) use and can be driven on with a standard, passenger car.

${ }^{39}$ The name Belveren (Belören) speaks for itself, as it means "a ruin of a col/pass". For Mağara see Hild - Hellenkemper 1990, 334.

${ }^{40}$ In 2014 a mission of the Istanbul University located several milestones in vicinity of Susama. Şahin Özdizbay 2016, 534-537; see also: Şahin 2019, 186-87 (similar, though without specifically naming Susama).

${ }^{41}$ It is not very frequented nowadays and has not been so far attested, though locals call it "an old caravan road". For Avgadı see Hild - Hellenkemper 1990, 203.

${ }^{42}$ Bahar 2007, 241.

${ }^{43}$ Belke 1984, 156.

${ }^{44}$ Hild - Hellenkemper 1990, 440.

45 This is most probably what Davis calls "Kara Tash Yaila Pass, a good level road" (today Karataş Gediği). Davis 1879, 318. Near Sorgun, there is a fortified inselberg with a church of which only a rockcarved apse remains (Fig. 31).

${ }^{46}$ Hild - Hellenkemper 1990, 200.

${ }^{47}$ In their description, Hellenkemper and Hild focus exclusively on "left bank" passes, and channel them all via Kemer yayla (Straßenknotenpunkt). This was an important point indeed though the road network here was far more complex and number of passes seems greater. See: Hellenkemper - Hild 1986, 89 and Hild - Hellenkemper 1990, 140. 
use. From Kayaönü it followed Buğdaylı creek upstream and ascended to a part of the plateau which was better supplied with water and pastures.

It ran as follows:

- Küçükkoraş - various spolia by a mosque built of reused ashlars.

- Kayaönü - seemingly the kilise-camii.

- Kale - tepe with a large, cylindrical cistern atop.

- Kilıçmezarı mevkii - settlement and an isolated spot nearby called Kilise with two cylindrical cisterns, possibly small monastery (Fig. 30).

- Çimenkuyu yaylası - a settlement with a church (spolia) where it began to converge with the modern road to Dümbelek Pass (Fig. 32). ${ }^{48}$

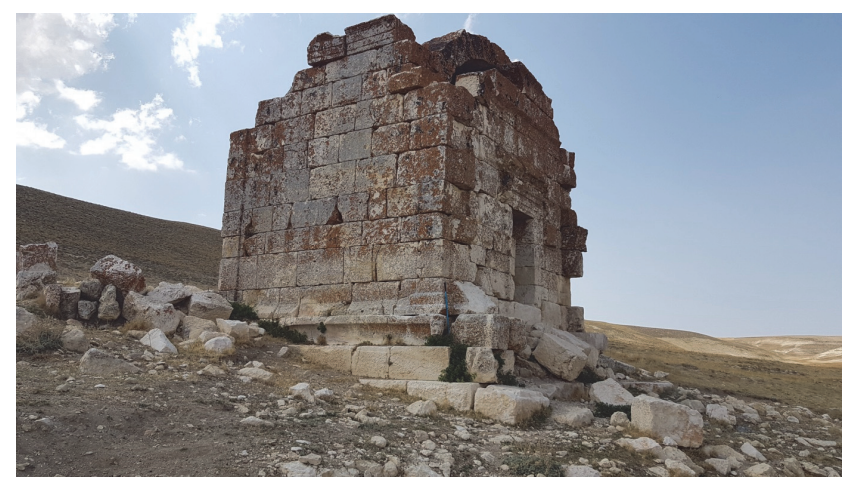

Fig. 28) Susama, tomb from southeast., Roman temple

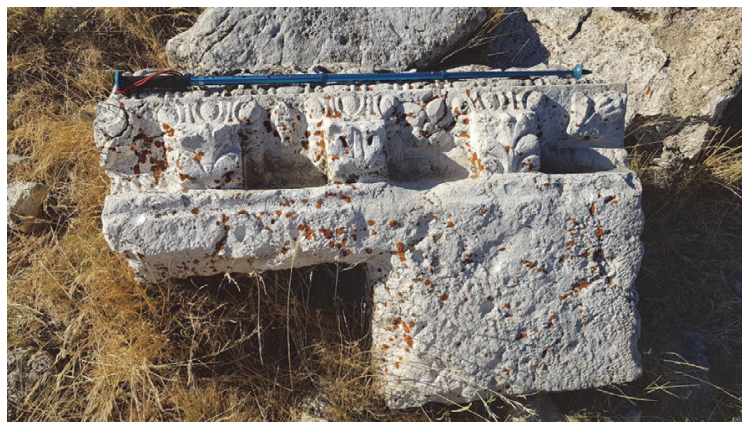

Fig. 29) Susama, temple, detail

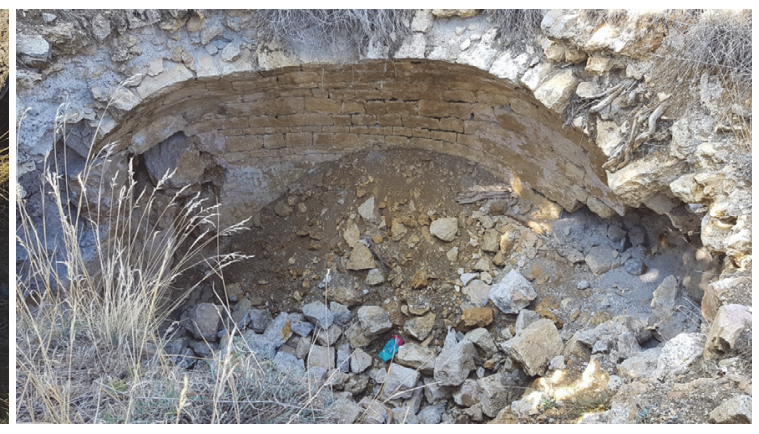

Fig. 30) Kilise at Kılıçmezarı mevkii, cistern

${ }^{48}$ Davis' judgment of this Pass was very favorable: "I do not consider it at all difficult. It seemed an open, easy road, and I am convinced that, excepting at one or two spots, which might easily be rendered practicable, even heavy artillery could be transported by this pass in its present state." Davis 1879, 318. According to Hogarth, details of this road were communicated by Col. J. D. H. Stewart to Ramsay in the following order: Karaman - Küçükkoraş - Dümbelek Pass. Hogarth - Munro 1893, 15. Mutafian considers it the most likely path that Menon and Epyaxa had taken. Mutafian 1988, 123, 286. Belke seems to ignore this road stating that: "Der östlichste lykaonische Taurusübergang... erreichte über Divle (amtlich Üçharman) oder direkt über Küçükkoraş den Scheitelpunkt bei Dedeli yayla...” and: “Der offensichtlich bedeutende Taurusübergang ist durch die Siedlungslagen von Divle, Divazkoraş (?) u. Dedeli Yayla in Lykaonien, Cacık u. Yelkalesi in Kilikien markiert". Though "Divazkoraş" may be regarded as understandable coalescence pointing to Divaz-Pınarkaya former administrative subordination to Büyükkoraş and both villages closeness, it must be taken into notice that Küçükkoraş is a separate entity. Belke 1984, $110,156$. 


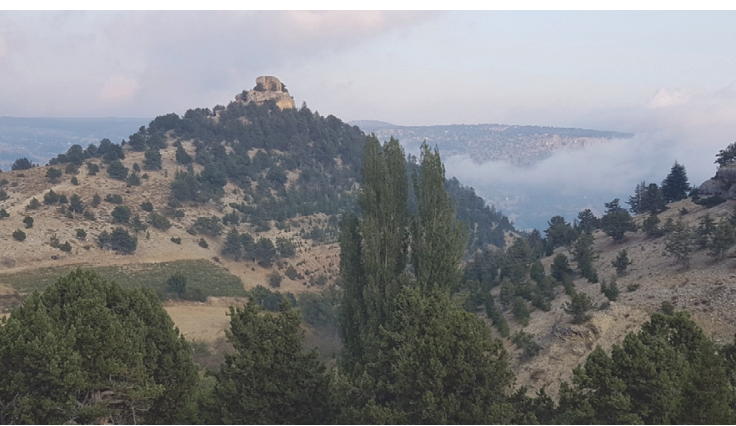

Fig. 31) Sorgun castle from north

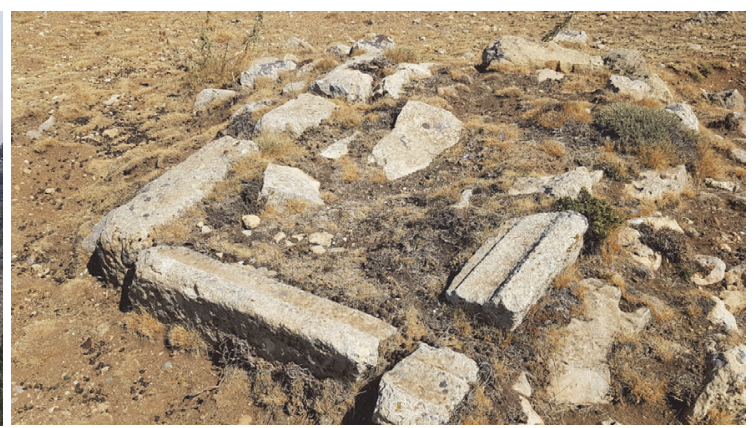

Fig. 32) Graveyard near Kilise at Çimenkuyu yaylası

Additionally, south of this track there is place called Gömücek (or Gömürcek) with a number of spolia, especially by a mosque (Fig. 33-Fig. 34). North of it there is a mountain peak (Ziyaret Dağı), with a türbe called Bulgar Bozoğlan - holy place of Tahtacı Turkmens. Though the shrine is entirely rebuilt with concrete, there are few ashlars and pieces of Byzantine entablature built into it. ${ }^{49}$

The importance and role of these passes evolved over time. It seems that Plinius's Thebasa owed much of its celebritas to the commercial significance of that network. The growth of settlement numbers scattered over this section of Taurus with their distinct ecclesiastic remains from the fifth to seventh centuries, coincide with what $S$. Mitchell has observed regarding the significance and development pattern of the harbour at Corycus during late antiquity. ${ }^{50}$ The Thebasa - Corycus connections seem to have been a crucial axis of prosperity for the local communities. However, the Arab seizure of Cilicia paralyzed this thriving area and turned it into unfriendly borderland. Further, this new pressure from the Muslims shifted the communication lines westward and thus precipitated Thebasa's decay in the late seventh century.

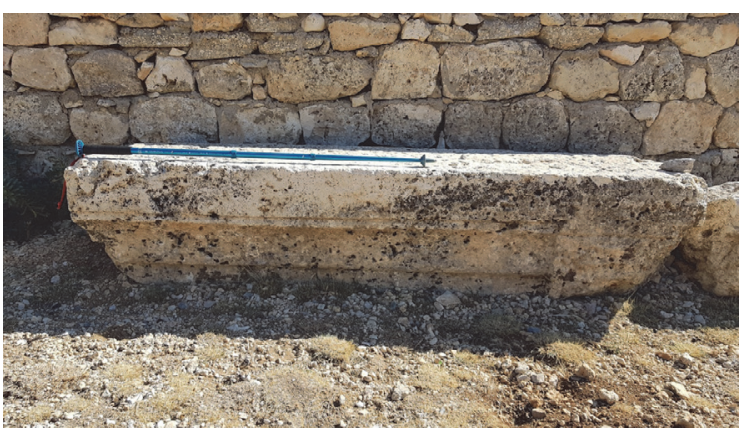

Fig. 33) Gömücek Camii, from north, detail

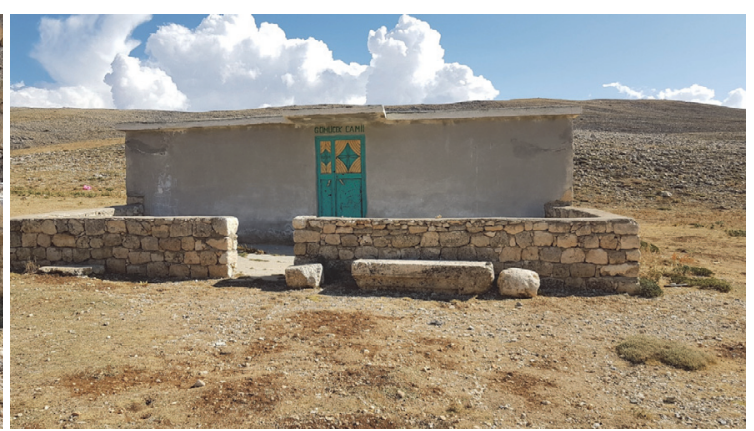

Fig. 34) Gömücek Camii from north

The city re-emerged and was briefly resurrected at the end of eight century as a military outpost. In this capacity it brought new life to mountain passes: roads abandoned by merchants were rediscovered by warriors. Strongholds in Arslanköy, Gediği, Evciler, Çandir, as well as unattest-

49 Though spolia may have originated from elsewhere (particularly Çimenkuyu yaylası church less than $4 \mathrm{~km}$ away) and had been brought here as a sort of vota, I was told by one of my interlocutors that there used to be an old, stone chapel (şapel) before, which could point to a Byzantine sanctuary or maybe a hermitage.

50 "By far the most important settlement here in late antiquity was the harbor city of Corycus. In the first three centuries Corycus remained only of local importance, but from the fourth to the sixth century the settlement boomed." Mitchell 2015, 366. 
ed forts in Sorgun, Böğrüeğri and Kaklıktaşı - to name only fortifications that predate Armenian building interventions - demonstrate how critical this passage was for the security of central Cilicia. But since the principal target of this activity was Tarsus, only "left bank" passes benefited from this temporary, military revival. The territory west of Lamos remained unsafe at least until the Byzantine conquest of Cilicia in 964-965, and consequently the arteries of communication seized up. For Corycus and its rich hinterland, this protracted coma proved too long. The city never fully recovered and its place was overtaken by Seleuceia-Silifke. The road network, described above, was in consequence also forsaken, and Thebasa fell into ultimate oblivion. ${ }^{51}$

\section{Conclusions}

A famous city of Lycaonia, an episcopal seat, a strategic military base - Thebasa has been searched for almost two centuries with at least eight different locations considered. Its position away from the main, or rather known routes, concealed it not only from assailants, but from scholars and travelers as well. Now that we grasp the complexity of its rises and falls, we can comprehend why this has happened. Furthermore, the position of Thebasa much deeper in Taurus than previously assumed and the presence of interconnected settlements on both sides of the mountains, allow one to suppose that tectonics of the land in confinio Lycaoniae atque Ciliciae was much more complex and looked different from what was hitherto believed. This is to say, that the links with the coast, rather than any other ones, were of supreme importance for regional economy and security.

The above proposed identification in Divaz-Pınarkaya will, I hope, encourage research by specialists in situ. Knowledge of the site and the settlement would be certainly improved by a thorough inventory of the spolia, many of which are hidden from the eyes of a passerby. What the author had an opportunity to witness is also thanks to the kindness of the residents who showed him the nooks and crannies of their homesteads. There are reportedly some stones stored in the Karaman Museum. It would not be improper to check whether they bear any epigraphic evidence.

Otherwise it seems highly advisable to carry out some immediate rescue works as degradation of the monuments of ancient Thebasa is progressing with drastic speed: according to testimony of local residents, damage to the vault of the cistern occurred just a few weeks before my visit in June 2019. The magnificent lintel that I still saw hanging over window of a house in October 2019, in March 2020 was lying in the debris of this freshly ruined house. In December 2020 this exquisite piece of masonry was already gone and I wonder how many similar remains have been irreversibly lost over the last years. ${ }^{52}$

\footnotetext{
${ }^{51}$ But even then history could not entirely prevail over geography. As Hogarth reported: „Two other roads of some importance traverse the Low Taurus; one leads from Karaman direct to Mersina and passes through Korash. The other crosses this at Korash, in its course from Eregli to Mahra, a village situated on the Karaman-Selefke road.”. Since Korash is Büyükkoraş, just $2 \mathrm{~km}$ away from Divaz/Pınarkaya, this crossroad refers in fact to the latter one. Hogarth - Munro 1893, 15.

${ }^{52}$ Since concrete has become relatively cheap and easily available, cut stones are not so much in demand anymore, I have found a few ashlars and even fine pieces of masonry at a village dump, where debris from ruined houses is being deposited.
} 


\section{Bibliography}

Primary sources

Plin. HN

Mich. Syr.

Theophanes

Tabari

\section{Secondary sources}

Ainsworth 1875

Bahar 2007

Belke 1984

Bonner 1996

Canard 1962

Cramer 1832

Darrouzès 1981

Davis 1879

Haldon - Kennedy 1980

Hamilton 1842

Hellenkemper - Hild 1986

Hild - Hellenkemper 1990
Plinius, Natural History, Vol. 5, translated by H. Rackham, Cambridge MA 1961.

Michel le Syrien, Chronique, T. III, edited and translated into French by J. B. Chabot, Paris 1905.

The Chronicle of Theophanes Confessor: Byzantine and Near Eastern History AD 284-813, translated by C. Mango - R. Scott, Oxford 1997.

The History of al-Tabari, Vol. XXX, The Abbasid Caliphate in equilibrium. The caliphates of Musa al-Hadi and Harun al-Rashid A.D. 785-809/A.H. 169-193, translated and annotated by C. E. Bosworth, Albany 1989.

W. F. Ainsworth, A commentary on the Anabasis of Xenophon, in: The Anabasis, or Expedition of Cyrus, and the Memorabilia of Socrates. Literally translated from the Greek of Xenophon by the Rev. J. S. Watson, London 1875.

H. Bahar, Konya-Karaman Yüzey Araştırmaları 2006, AST 25/1, 2007, 235-254.

K. Belke, mit Beiträgen von M. Restle, Galatien und Lykaonien, Wien 1984.

M. Bonner, Aristocratic Violence and Holy War. Studies on the Jihad and the Arab-Byzantine Frontier, New Haven 1996.

M. Canard, La prise d'Héraclée et les relations entre Hārūn arRashīd et l'empereur Nicéphore 1er, Byzantion 32, 1962, 345-79.

J. A. Cramer, A Geographical and Historical Description of Asia Minor with a Map, Vol. 2, Oxford 1832.

J. Darrouzès, Notitiae Episcopatuum Ecclesiae Constantinopolitanae, Paris 1981.

E. J. Davis, Life in Asiatic Turkey, London 1879.

J. Haldon - H. Kennedy, The Arab-Byzantine Frontier in the Eighth and Ninth Centuries: Military Organization and Society in the Borderlands, Zbornik Radova Vizantološkog Instituta XIX, 1980, 79-116.

W. J. Hamilton, Researches in Asia Minor, Pontus and Armenia; with some account of their antiquities and geology, Vol. 2, London 1842 .

H. Hellenkemper - F. Hild, Neue Forschungen in Kilikien, Wien 1986.

F. Hild - H. Hellenkemper, Kilikien und Isaurien, Wien 1990. 
Hogarth - Munro 1893

Jones 1971

Konyalı 1970

Laminger-Pascher 1992

Lilie 1976

Lilie 1996

Mitchell 2015

Mordtman 1861

Mutafian 1988

Perrot - Guillaume 1872

Ramsay - Bell 1909

Ramsay 1890

Ramsay 1904

Ritter 1859

Rott 1908

Ruge 1934

Shaban 1976

Şahin - Özdizbay 2016

Şahin 2019
D. G. Hogarth - J. A. R. Munro, Modern and Ancient Roads in Eastern Asia Minor, London, 1893.

A. H. Jones, The Cities of the Eastern Roman Provinces, Oxford 1971.

İ. H. Konyalı, Abideleri ve Kitâbeleri ile Konya Ereğli'si Tarihi, Istanbul 1970.

G. Laminger-Pascher, Die Kaiserzeitlichen Inschriften Lykaoniens Faszikel 1: Der Süden, Wien 1992.

R. J. Lilie, Die Byzantinische Reaktion auf die Ausbreitung der Araber. Studien zur Strukturwandlung des Byzantinischen Staates im 7. und 8. Jahrhundert, München 1976.

R. J. Lilie, Byzanz unter Eirene und Konstantin VI (780-802), Frankfurt am Main 1996.

S. Mitchell, A History of a Later Roman Empire, ed. 2, Malden MA 2015.

A. D. Mordtman, Bogazköi und Üyük. Dritter Beitrag zur vergleichenden Erdkunde von Kleinasien, in: Sitzungsberichte der Königlich Bayerischen Akademie der Wissenschaften zu München, B. 1, 1861, 169-198.

C. Mutafian, La Cilicie au carrefour des empires, T. 1-2, Paris 1988.

G. Perrot - E. Guillaume, Exploration Archéologique de la Galatie et de la Bithynie, Vol. 1, Paris 1872.

W. M. Ramsay - G. L. Bell, The Thousand and One Churches, London 1909.

W. M. Ramsay, The Historical Geography of Asia Minor, London 1890.

W. M. Ramsay, Lycaonia, Jahreshefte des Österreichischen Archäologischen Institutes in Wien, B. 7, 1904, 57-132.

C. Ritter, Vergleichende Erdkunde der Halbinsellandes KleinAsien, B. 2, Berlin 1859.

H. Rott, Kleinasiatische Denkmäler aus Pisidien, Pamphylien, Kappadokien und Lykien, Leipzig 1908.

W. Ruge, Thebasa in: Paulys Realencyclopädie der classischen Altertumswissenschaft, B. V, A, 2, Stuttgart 1934, 1594.

M. A. Shaban, Islamic History. A New Interpretation, Vol. 2, AD 750-1055 (AH 132-448), Cambridge 1976.

H. Şahin - A. Özdizbay, Dağlık Kilikia Yerleşim Tarihi ve Epigrafya Araştırmaları 2014-2015, in: 34. Araştırma Sonuçları Toplant1s1, 2 cilt, Edirne 2016, 505-550.

H. Şahin, CIL XVII, 5, 3: Neue Meilensteine und Straßen aus der 
Texier 1849

Treadgold 1988

Treadgold 1997

Cilicia Aspera, in: Roman Roads: New Evidence - New Perspectives, Berlin-Boston 2019, 166-190.

C. Texier, Description de l'Asie Mineure: faite par ordre du gouvernement français en 1833-1837, Vol. 2, Paris 1849.

W. Treadgold, The Byzantine Revival, 780-842, Stanford 1988.

W. Treadgold, A History of the Byzantine State and Society, Stanford 1997.

\section{Thebasa ve Orta Toroslar Bölgesi'nin Bizans-Arap Sınırı. Confinio Lycaoniae atque Ciliciae'daki Gözlemler \\ Öz}

Bu makale, Karaman ilindeki Pınarkaya'da (Divaz) bulunan Lykaonia kenti Thebasa'nın yeni bir konumunu önermekte ve önceki teşhislere ilişkin eleştirisel bir analiz sunmaktadır. Kentsel/dini bir merkezden stratejik askeri bir üsse dönüşümüne işaret eden daha kapsamlı tarihi coğrafi bağlamında Thebasa'nın önemini yeniden değerlendiriyor. Bir takım yayınlanmamış site vasıtasıyla makale Orta Toros Bölgesi'nin yerleşim ve iletişim ağlarına yeni bir bakış sunuyor. Bu bağlamda, 8. ve 9. yüzyıllarının dönümünde Bizans-Arap ilişkilerinin dinamiklerine dair yeni yorumlar da geliştirmektedir.

Anahtar Sözcükler: Thebasa, Lykaonia, Kilikia, Tauros Geçitleri, Bizans-Arap sınırı, Bizans-Arap ilişkileri.

\section{Thebasa and the Byzantine-Arab frontier of the Middle Taurus Region. \\ Observations in confinio Lycaoniae atque Ciliciae}

\section{Abstract}

This paper proposes a new location for the Lycaonian city of Thebasa at Pinarkaya (Divaz) in the province (il) of Karaman and provides a critical analysis of its previous identifications. It revaluates the importance of Thebasa in a broader, geo-historical context pointing out its transformation from a urban/ecclesiastic center to a strategic military base. Through several unpublished sites, the paper presents a fresh look at the settlement and communication networks of the Middle Taurus Region. Within this context it also develops new interpretations of the dynamics of Byzantine-Arab relations at the turn of the eighth and ninth centuries.

Keywords: Thebasa, Lycaonia, Cilicia, Taurus passes, Byzantine-Arab frontier, Byzantine-Arab relations. 